Review

\title{
Anaerobic digestion of pulp and paper mill wastes - An overview of the developments and improvement opportunities
}

\author{
Mohammadreza Kamali ${ }^{\mathrm{a}, \mathrm{b}, *}$, Tânia Gameiro ${ }^{\mathrm{a}}$, Maria Elisabete V. Costa ${ }^{\mathrm{b}}$, Isabel Capela ${ }^{\mathrm{a}}$ \\ ${ }^{a}$ Department of Environment and Planning, Center for Environmental and Marine Studies, CESAM, University of Aveiro, $3810-193$ Aveiro, Portugal \\ ${ }^{\mathrm{b}}$ Department of Materials and Ceramics Engineering, Aveiro Institute of Materials, CICECO, University of Aveiro, 3810-193 Aveiro, Portugal
}

\section{H I G H L I G H T S}

- Historical perspective of P\&P mill wastes anaerobic digestion is critically reviewed.

- Recent progress in anaerobic digestion of P\&P mill wastes is reviewed and discussed.

- Combined methods are proposed as promising technologies for P\&P wastes treatment.

\section{G R A P H I C A L A B S T R A C T}

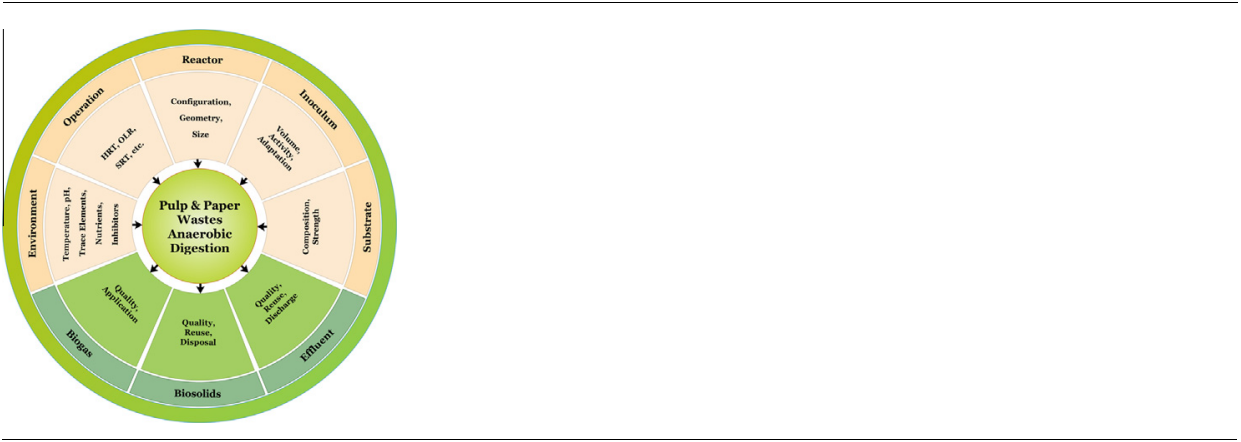

\section{A R T I C L E I N F O}

\section{Article history:}

Received 8 October 2015

Received in revised form 19 March 2016

Accepted 22 March 2016

Available online 30 March 2016

\section{Keywords}

Pulp and paper industry

Wastewater

Sludge

Anaerobic digestion

Methane production

\begin{abstract}
A B S T R A C T
Various organic and inorganic hazardous substances are commonly originated during the processing of virgin or recovered fibers (RCFs), when the pulp and paper (P\&P) are produced. Hence, pulp and paper industry (PPI) strongly need to employ advanced waste treatment processes as a powerful tool to comply with the stringent environmental regulations in one hand, and to increase their profitability in the current declining P\&P markets, on the other hand. Among the treatment alternatives, anaerobic digestion (AD), is an interesting cost effective alternative with a small environmental footprint and has been increasingly adopted by the PPI to reach this goal. However, the application of AD to deal with wastes generated in P\&P mills has been restricted due to a number of limitations, regarding the anaerobic reactor design and the operating conditions. Hence, the optimization of the AD performance would be a crucial step in order to increase the economic benefits, and also to satisfy the strict environmental protection standards. To this end, this paper presents an overview on the current state of the developments associated with AD treat ment of P\&P mill wastes to assess the applicability of this treatment process for the management of this type of complex wastes. In this context, suggestions are provided to maximize both biogas production and removal efficiency, focusing on the relationship between waste composition and reactor design and operational conditions, which will enhance methane capture and contribute to prevent global warming.
\end{abstract}

(c) 2016 Elsevier B.V. All rights reserved.

\section{Contents}

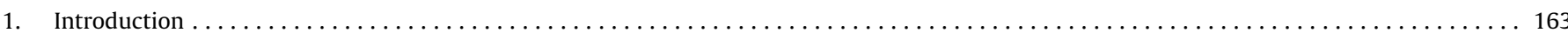

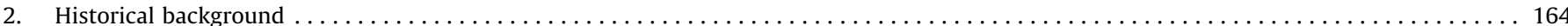

* Corresponding author at: Department of Environment and Planning, Center for Environmental and Marine Studies, CESAM, Department of Materials and Ceramics Engineering, Aveiro Institute of Materials, CICECO, University of Aveiro, 3810-193 Aveiro, Portugal.

E-mail address: Kamali@ua.pt (M. Kamali). 


$\begin{array}{ll}\text { Nomenclature } \\ \text { ABR } & \text { anaerobic baffled reactor } \\ \text { AD } & \text { anaerobic digestion } \\ \text { AFs } & \text { anaerobic filters } \\ \text { AOPs } & \text { advanced oxidative processes } \\ \text { AOXs } & \text { adsorbable organic halogens } \\ \text { AnMBRs } & \text { anaerobic membrane bioreactor } \\ \text { BI } & \text { biodegradability index } \\ \text { BOD } & \text { biochemical oxygen demand } \\ \text { COD } & \text { chemical oxygen demand } \\ \text { CP } & \text { chemical pulping } \\ \text { CTMP } & \text { chemical thermo mechanical pulping } \\ \text { DCP } & \text { dichlorophenol } \\ \text { ECF } & \text { elemental chlorine free } \\ \text { ENMs } & \text { engineered nanomaterials } \\ \text { FBRs } & \text { fluidized bed reactors } \\ \text { HRT } & \text { hydraulic retention time } \\ \text { KP } & \text { kraft pulp } \\ \text { LTAD } & \text { low temperature anaerobic digestion } \\ \text { MP } & \text { mechanical pulping } \\ \text { NPs } & \text { nanoparticles } \\ \text { OLR } & \text { organic loading rate } \\ \text { P\&P } & \text { pulp and paper }\end{array}$

$\begin{array}{ll}\text { PPI } & \text { pulp and paper industry } \\ \text { PPMW } & \text { pulp and paper mill wastewater } \\ \text { PPMS } & \text { pulp and paper mill sludge } \\ \text { PPS } & \text { pulp and paper sludge } \\ \text { PVDF } & \text { polyvinylidine fluoride } \\ \text { RCF } & \text { recovered fiber } \\ \text { SAnMBRs } & \text { submerged anaerobic membrane bioreactors } \\ \text { SBR } & \text { sequencing batch reactor } \\ \text { SCOD } & \text { soluble chemical oxygen demand } \\ \text { SCP } & \text { semi chemical pulping } \\ \text { SRT } & \text { solids retention time } \\ \text { SGBR } & \text { static granular bed reactor } \\ \text { SPC } & \text { sulfonated polycarbonate } \\ \text { TCF } & \text { total chlorine free } \\ \text { TCOD } & \text { total chemical oxygen demand } \\ \text { TDS } & \text { total dissolved solids } \\ \text { TSS } & \text { total suspended solids } \\ \text { TMP } & \text { thermomechanical pulping } \\ \text { UASB } & \text { upflow anaerobic sludge blanket } \\ \text { UAF } & \text { upflow anaerobic filter } \\ \text { UAPBR } & \text { upflow anaerobic packed bed reactor } \\ \text { VFAs } & \text { volatile fatty acids }\end{array}$

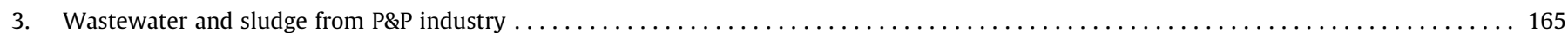

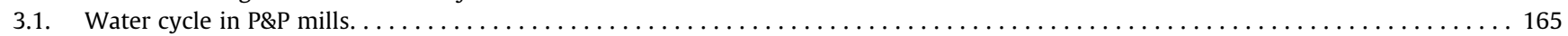

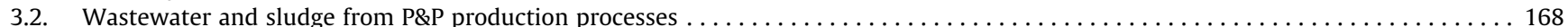

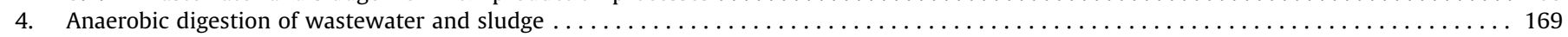

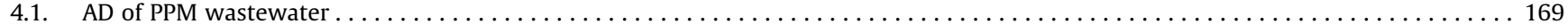

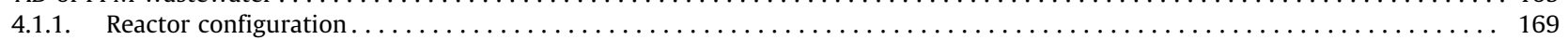

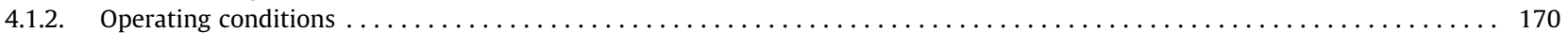

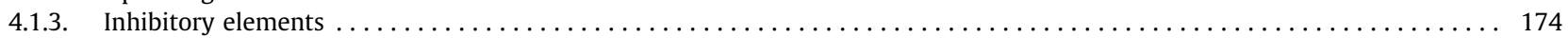

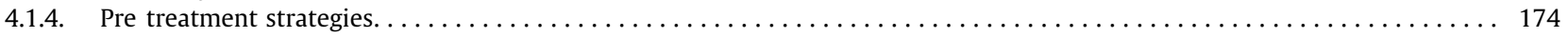

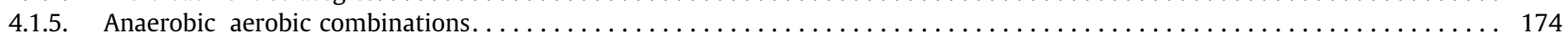

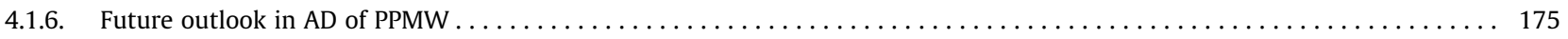

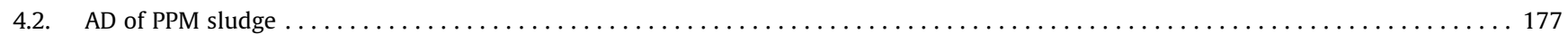

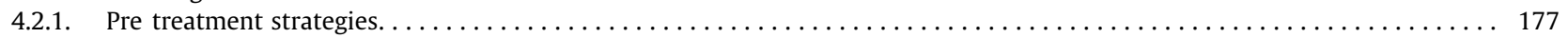

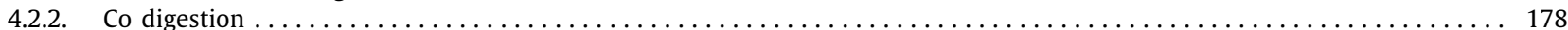

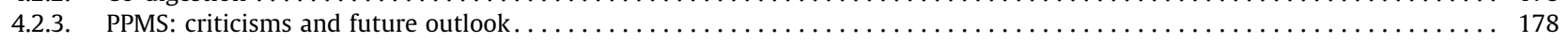

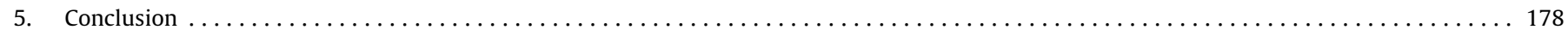

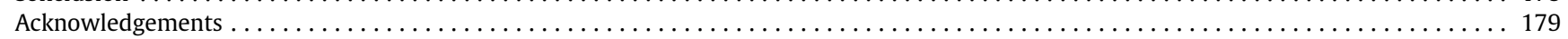

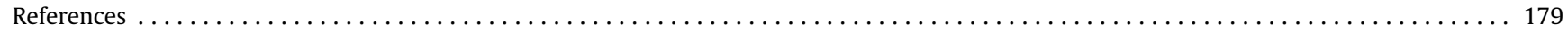

\section{Introduction}

Various wood or non wood materials are the main raw materi als for the production of pulp and paper (P\&P) in many countries through the world (Fig. 1). Moreover, P\&P manufacturing from recovered fibers (RCFs) has been increased during recent years [1]. After preparation of stock materials, steps including pulping, bleaching, and P\&P making are applied, respectively, to yield pulp or paper as final products (Fig. 2). Based on the raw materials used and the manufacturing process adopted, P\&P industry (PPI) pro duce relatively large amounts of both wastewater and solid wastes [2]. On site, reuse and recycling, and also modifications in the technology [3] are among the most efficient economic and environmental options dealing with the produced residues. In this regard, measures for minimizing the produced wastes, and recov ery of energy and unavoidable wastes have been introduced [4] and adopted by PPI [5]. However, the external waste treatments are still the main ways to deal with the residues from PPIs, especially for small and medium size units which generally do not benefit of infrastructures for the recovery of chemicals [6]. So far, various types of treatments (primary, secondary, and tertiary) have been developed and applied in order to enhance the treat ment efficiency of both pulp and paper mill wastewater (PPMW) and sludge (PPMS) with the aim of reducing the amount of the pro duced final wastes, and also to prevent the probable subsequent toxic effects induced by the presence of hazardous compounds when released into the receiving environment [7].

Anaerobic digestion (AD), defined as the biological degradation of organic compounds into different end products, including methane (50 75\%), carbon dioxide (25 50\%), hydrogen (5 10\%), and nitrogen ( $12 \%$ ) [8] by a microbial consortium in the absence of air [9], has been widely employed for primary or secondary treatment of various industrial residues. The development of methods for the AD process control and monitoring [10] as well as the operational conditions set up has raised a large interest in recent studies. This is mainly due to the advantages of $A D$ over conventional biological P\&P waste treatment, such as a significant reduction of the produced wastes and the production of biogas, mainly composed by methane. Despite these advantages, some improvements in the stability of the process, in methane yields, 


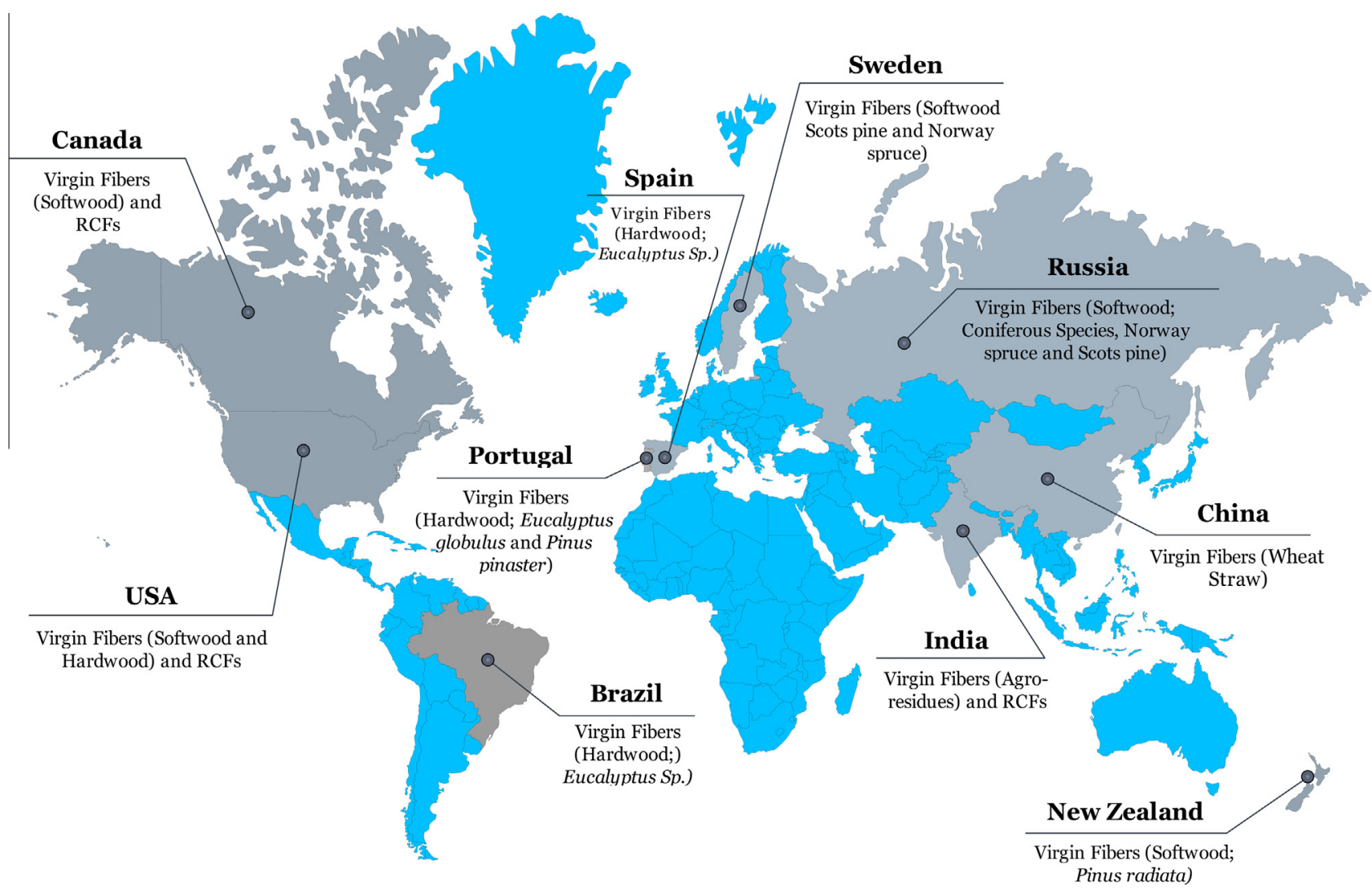

Fig. 1. Predominating raw materials for P\&P production in some main [20] P\&P producers [21-30].

and regarding inhibition problems are still necessary to enhance the AD performance, especially when dealing with non biodegradable and recalcitrant pollutants such as halogenated organic compounds present in P\&P residues. Hence, when AD is used to treat wastes from P\&P industry, the adoption of appropri ate anaerobic reactor configuration and operating conditions can potentially promote methane production. Framed by this concern, the present study critically reviews the recent developments on $\mathrm{AD}$ bioreactor technologies used for the treatment of wastes generated by P\&P mills and their relationship with the specific characteristics of the PPMW and waste sludge produced, depending on the P\&P production process. In this context, previously published review papers addressing the various concepts of AD in general [11 17] or specific aspects of the AD of P\&P mill wastes [18], [19] have also been taken into consideration to provide a broader overview and to emphasize that a choice among various available technologies are likely to be case specific, needing also an economic evaluation. However, to focus on the technology with the highest potential for implementation in the PPI, it is important to discuss the recently developed high rate anaerobic reactors together with the impact of the various environmental factors on the perfor mances of the AD process. Hence, these aspects and their possible improvements are also discussed aiming at the optimization of the $\mathrm{AD}$ process and its adoption in the treatment of such high strength complex wastes. Furthermore, considering the remaining weak nesses and the developments of anaerobic reactors for the treat ment of other streams, suggestions for further studies in the form of future outlook are presented in the manuscript.

\section{Historical background}

It is believed that biogas was used for the first time in Assyria in the 10th century B.C for bath water heating [31]. However, it was during the period 18041808 that John Dalton and Humphrey Davy discovered that the flammable gas in the biogas composition is methane [32]. Although the production of methane through the anaerobic conversion or digestion of animal and human wastes, as a source of energy, has a long history in many areas of the world [10], the first anaerobic digester was built in 1859 in a leper colony in Bombay, India, with the aim of converting the wastes to energy [33]. Bechamp (1868) and Popoff (1873) stated that biological pro cesses are responsible for methane formation [34]. Omelianski, in the 1890s, and Sohngen in 1910 stated that the reaction between hydrogen and carbon dioxide, induced by biological agents is the probable pathway for methane formation [35].

Since the beginning of the 20th century, AD has been widely used in many parts of world, and China has had the largest number of $\mathrm{AD}$ systems since the late nineteenth century [36]. In the mid 20th century, this technology was mainly used for the treatment of sewage sludge rather than industrial effluents [37]. Since then, the $\mathrm{AD}$ systems have been rapidly developed, especially after the first energy crisis back in the 1970's [38], with an increasing inter est to optimize the $A D$ process to treat high strength industrial wastes [39]. Upflow anaerobic sludge blanket reactor (UASB) was developed during 1970's and applied by Dutch sugar industry. However, the development of the high rate generation of anaerobic digesters only took place in 1980's, in order to decrease the hydraulic retention time (HRT), which was the main weakness of such systems. Since 1990's, the development and application of $\mathrm{AD}$ systems for simultaneous treatment and methane production from PPMW and sludge have found a considerable success [40]. Nowadays, AD, as a mature technology in most of European coun tries, is utilized for household energy production [41], as well as for the treatment of various organic wastes such as agricultural wastes, sewage treatment, and different industrial wastes such as textile industry wastewater, etc. Although P\&P mills generally pro duce a large amount of wastewater and solid wastes that contain 


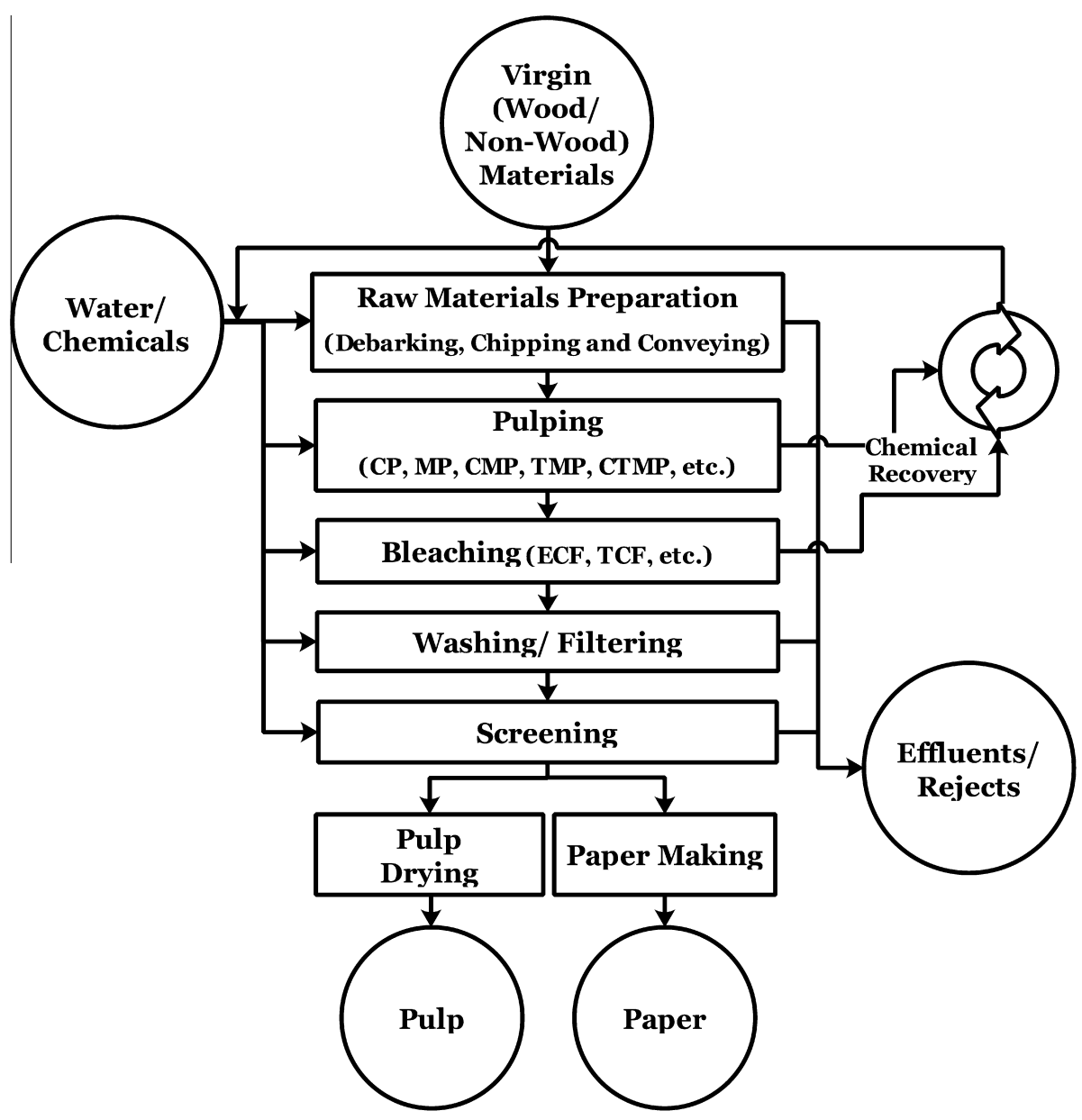

Fig. 2. A schematic P\&P production process from virgin fibres.

various pollutants (Table 1), the effluents from mechanical pulping (MP), RCFs processing, chemical pulping (CP) and semi chemical pulping (SCP), as well as from both primary and secondary sludge originated by PPMW treatment plants are not commonly toxic to methanogenic bacteria. Hence, adoption of $\mathrm{AD}$ process for the treatment of P\&P mill wastes has raised a large interest during the two recent decades. Designing new generations of anaerobic reactors, improving reactors operational conditions, and develop ing effective consortia of anaerobic bacteria have significantly enhanced the performance of the $\mathrm{AD}$ process for the treatment of various industrial wastes containing high levels of organic matter during the last decades [42].

\section{Wastewater and sludge from P\&P industry}

\subsection{Water cycle in PEP mills}

P\&P mill is a relatively high water dependent industry when compared with many other industries and, according to the stringent environmental regulations, is responsible for the management of the water resources they use. Such resources are generally being obtained from the surface and ground waters and after being used in almost all the major process stages (Fig. 2), and also for cooling the machines, cleaning the equipment, etc., form the main part of the liquid reject (effluents) from a P\&P industry (Fig. 3).

Due to the growing global concerns on the scarcity of water resources, the water management in water intensive industry, like PPI is of high importance and hence tough environmental regulations have been developed to ensure the sustainable use of the water resources in industrial water users. Although at the beginning of the last century the manufacturing processes in addition to other internal use required high amount of water (200 $1000 \mathrm{~m}^{3} /$ tone paper), this amount has been considerably decreased due mainly to the technological advances occurred in the P\&P production processes. As an example, German P\&P indus try has succeeded to reduce the water required for the production of a ton paper produced to just $13 \mathrm{~m}^{3}$ [43]. Moreover, in many countries such as USA and Canada, the volume of recovered paper produced has significantly increased in the past two decades (e.g., from 17.4 million metric tons to 49.3 million metric tons in USA) [30] leading to a decrease in the amount of the wastewater gener ated for the production of P\&P, due to the RCF mills being less water intensive when compared with virgin P\&P producers [44].

Although the industry is a large user of water resources, only a small part of the water resource they use is consumed during the manufacturing related activities in a typical P\&P mill. For instance, in United States, about $88 \%$ of the intake water is returned to the surface waters after being treated, while just $11 \%$ of it is evapo rated and $1 \%$ is embedded in products or in solid wastes (Fig. 3) [45]. Accordingly, advanced treatment processes applied to the P\&P mill wastes can significantly aid P\&P producers to improve the quality of the effluents satisfying the environmental regula tions. Moreover, some internal treatment processes can be pro vided in order to re use the water during the manufacturing processes. For instance, Wang, Chen, Wang, Yuan, \& Yu (2011) [46] through the application of aluminum chloride as a coagulant and a modified natural polymer (starch $g$ PAM g PDMC) as a 
Table 1

Main rejects to the PPMW from P\&P making processes using virgin or RCFs.

\begin{tabular}{|c|c|c|c|c|c|c|c|c|c|c|c|c|}
\hline \multirow{3}{*}{$\begin{array}{l}\text { Fibrous } \\
\text { raw } \\
\text { materials }\end{array}$} & \multirow[t]{3}{*}{ Operation } & \multirow[t]{3}{*}{ Main processes } & \multirow[t]{3}{*}{ Main additives } & \multirow[t]{3}{*}{ Main rejects } & \multicolumn{7}{|c|}{ Typical effluents parameters } & \multirow[t]{3}{*}{ References } \\
\hline & & & & & \multirow[t]{2}{*}{ Process } & \multirow[t]{2}{*}{$\mathrm{pH}$} & \multirow[t]{2}{*}{$\mathrm{COD}(\mathrm{mg} / \mathrm{L})$} & \multirow{2}{*}{$\begin{array}{l}\text { BOD } \\
(\mathrm{mg} / \\
\mathrm{L})\end{array}$} & \multirow{2}{*}{$\begin{array}{l}\text { TSS } \\
(\mathrm{mg} / \\
\mathrm{L})\end{array}$} & \multicolumn{2}{|c|}{ Other parameters } & \\
\hline & & & & & & & & & & Type & Quantity & \\
\hline \multirow[t]{11}{*}{$\begin{array}{l}\text { Virgin } \\
\text { fiber }\end{array}$} & $\begin{array}{l}\text { Raw } \\
\text { materials } \\
\text { operation }\end{array}$ & $\begin{array}{l}\text { Debarking, chipping } \\
\text { and conveying }\end{array}$ & - & $\begin{array}{l}\text { Bark, tannin, lignin, } \\
\text { hemicelluloses and some } \\
\text { large amounts of organic } \\
\text { compounds such as resin } \\
\text { acids as well as soil and dirt }\end{array}$ & $\begin{array}{l}\text { Wood } \\
\text { yard and } \\
\text { chipping }\end{array}$ & 7 & 1275 & 556 & 7150 & - & - & {$[28,54-56]$} \\
\hline & \multirow{5}{*}{$\begin{array}{l}\text { Pulping } \\
\text { (paper } \\
\text { grade or } \\
\text { dissolving } \\
\text { grade) }\end{array}$} & \multirow{5}{*}{$\begin{array}{l}\text { Sulfate pulping } \\
\text { (kraft) and sulfite } \\
\text { pulping, } \\
\text { Thermomechanical } \\
\text { Pulping (TMP) } \\
\text { Chemical thermo- } \\
\text { mechanical pulping } \\
\text { (CTMP)MPCMP }\end{array}$} & \multirow{5}{*}{$\begin{array}{l}\text { Sodium hydroxide }(\mathrm{NaOH}) \text {, sodium } \\
\text { sulfide }\left(\mathrm{NaS}_{2} \text { ) (kraft pulping), and }\right. \\
\text { some other inorganic compounds, } \\
\text { such as } \mathrm{Na}_{2} \mathrm{CO}_{3}, \mathrm{NaHCO}_{3}, \mathrm{Na}_{2} \mathrm{SO}_{4} \text {, } \\
\mathrm{Na}_{2} \mathrm{SO}_{3} \text {, and } \mathrm{Na}_{2} \mathrm{~S}_{2} \mathrm{O}_{3} \text { (sulfite } \\
\text { process), etc. }\end{array}$} & $\begin{array}{l}\text { Knots, uncooked woods, bark } \\
\text { particles, soluble wood }\end{array}$ & $\begin{array}{l}\text { Kraft } \\
\text { cooking }\end{array}$ & 13.5 & 1669.7 & 460 & 40 & - & - & \multirow[t]{5}{*}{$\begin{array}{l}{[28,47,56-} \\
63]\end{array}$} \\
\hline & & & & $\begin{array}{l}\text { materials Color, resin acids } \\
\text { (Including Isopimaric, } \\
\text { sandacopimaric, levopimaric, } \\
\text { abietic, dehydroabietic, }\end{array}$ & TMP & $4.0-4.2$ & $3343-4250$ & - & $\begin{array}{l}330- \\
510\end{array}$ & $\begin{array}{l}\mathrm{TN}^{\mathrm{a}} \\
\mathrm{TP}^{\mathrm{b}}\end{array}$ & $\begin{array}{l}0.01-0.02 \\
(\mathrm{mg} / \mathrm{L}) \\
1.31-1.47 \\
(\mathrm{mg} / \mathrm{L})\end{array}$ & \\
\hline & & & & $\begin{array}{l}\text { neoabietic and palustric } \\
\text { acids), fatty acids, BOD, COD, } \\
\text { and dissolved inorganics, }\end{array}$ & $\mathrm{APMP}^{\mathrm{c}}$ & 7.43 & 7521 & 3000 & 350 & $\begin{array}{l}\text { Lignin } \\
\text { MTBE } \\
\text { extractives }\end{array}$ & $\begin{array}{l}516(\mathrm{mg} / \mathrm{L}) \\
147(\mathrm{mg} / \mathrm{L})\end{array}$ & \\
\hline & & & & Lignin, and hemicelluloses, & CTMP & 12 & 25,000 & 6800 & - & Color & 42,000 (C.U.) & \\
\hline & & & & $\begin{array}{l}\text { also somechemical additives } \\
\text { suchas soluble silicates }\left(3 \mathrm{SiO}_{2}\right. \\
\left.\mathrm{Na}_{2} \mathrm{O}\right)\end{array}$ & $\mathrm{MP}^{\mathrm{d}}$ & $6.1-8.1$ & $91-1150$ & $6-69$ & $\begin{array}{l}3- \\
45\end{array}$ & - & - & \\
\hline & \multirow[t]{3}{*}{ Bleaching } & \multirow[t]{3}{*}{$\begin{array}{l}\text { Chemical or } \\
\text { mechanical pulp } \\
\text { bleaching }\end{array}$} & \multirow{3}{*}{$\begin{array}{l}\text { Elemental chlorine free (ECF): } \mathrm{ClO}_{2} \\
\text { and } \mathrm{H}_{2} \mathrm{SO}_{4} \text { (in an acidic } \\
\text { environment) or } \mathrm{NaOH}, \mathrm{O}_{2} \text {, and } \\
\text { hydrogen peroxide (in an alkaline } \\
\text { phase). Total chlorine free (TCF): } \\
\mathrm{H}_{2} \mathrm{SO}_{4} \text {, ozone, chelating agents, and/ } \\
\text { or hydrogen peroxide }\end{array}$} & $\begin{array}{l}\text { Chlorophenols, AOX, EOXs, } \\
\text { polychlorinated biphenyls, } \\
\text { polychlorinated }\end{array}$ & $\begin{array}{l}\text { Kraft pulp } \\
\text { Bleaching }\end{array}$ & 8.50 & 426 & 25.50 & - & $\begin{array}{l}\text { Lignin } \\
\text { Phenol } \\
\text { AOX }\end{array}$ & $\begin{array}{l}50.00(\mathrm{mg} / \mathrm{L}) \\
0.535(\mathrm{mg} / \mathrm{L}) \\
2.82(\mathrm{mg} / \mathrm{L})\end{array}$ & \multirow[t]{3}{*}{$\begin{array}{l}{[28,55,57,64-} \\
68]\end{array}$} \\
\hline & & & & & Bleaching $^{\mathrm{e}}$ & 8.2 & 3680 & 352 & 950 & $\begin{array}{l}\text { Residual } \\
\text { chlorine }\end{array}$ & $9040(\mathrm{mg} / \mathrm{L})$ & \\
\hline & & & & $\begin{array}{l}\text { lignosulfonic acids, } \\
\text { chlorinated resin acids, } \\
\text { residual lignin, color, COD, } \\
\text { carbohydrate, inorganic } \\
\text { chlorines, VOCs, and } \\
\text { halogenated hydrocarbons }\end{array}$ & & & & & & $\begin{array}{l}\text { Chloride } \\
\text { content }\end{array}$ & $1340(\mathrm{mg} / \mathrm{L})$ & \\
\hline & Washing & $\begin{array}{l}\text { Bleached pulp } \\
\text { washing }\end{array}$ & $\begin{array}{l}\text { Solutions containing chemicals like } \\
\text { an alkali caustic soda }\end{array}$ & $\begin{array}{l}\text { Residual lignin, bleaching } \\
\text { agents and some hardly } \\
\text { biodegradable organic } \\
\text { compounds }\end{array}$ & - & - & - & - & - & - & - & [55] \\
\hline & $\begin{array}{l}\text { Paper- } \\
\text { making }\end{array}$ & $\begin{array}{l}\text { Dewatering, pressing } \\
\text { and drying, finishing }\end{array}$ & $\begin{array}{l}\text { Dyes, resins, fillers }{ }^{\mathrm{f}} \text {, sizing agents }{ }^{g} \text {, } \\
\text { binders, coating aids, strength } \\
\text { agent } \mathrm{t}^{\mathrm{h}} \text {, biocides, optical brighteners, } \\
\text { colournts, pigments, etc. }\end{array}$ & $\begin{array}{l}\text { Mineral additives, AOXs, } \\
\text { resins, BOD, COD, resin acids, } \\
\text { particulate wastes, etc. }\end{array}$ & $\begin{array}{l}\text { Paper } \\
\text { machine }\end{array}$ & 6.5 & 1116 & 641 & 645 & - & - & {$[58,69,70]$} \\
\hline
\end{tabular}




\begin{tabular}{|c|c|c|c|c|c|c|c|c|c|c|c|c|}
\hline \multirow{3}{*}{$\begin{array}{l}\text { Fibrous } \\
\text { raw } \\
\text { materials }\end{array}$} & \multirow[t]{3}{*}{ Operation } & \multirow{3}{*}{$\begin{array}{l}\text { Main } \\
\text { processes }\end{array}$} & \multirow[t]{3}{*}{ Main additives } & \multirow[t]{3}{*}{ Main rejects } & \multicolumn{7}{|c|}{ Typical effluents parameters } & \multirow[t]{3}{*}{ References } \\
\hline & & & & & \multirow[t]{2}{*}{ Process } & \multirow[t]{2}{*}{$\mathrm{pH}$} & \multirow{2}{*}{$\mathrm{COD}(\mathrm{mg} / \mathrm{L})$} & \multirow[t]{2}{*}{ BOD $(\mathrm{mg} / \mathrm{L})$} & \multirow[t]{2}{*}{ TSS (mg/L) } & \multicolumn{2}{|c|}{ Other parameters } & \\
\hline & & & & & & & & & & Type & Quantity & \\
\hline \multirow[t]{4}{*}{ RCFs } & \multirow[t]{3}{*}{$\begin{array}{l}\text { Pulping/ } \\
\text { deinking }\end{array}$} & \multirow[t]{3}{*}{$\begin{array}{l}\text { RCFs } \\
\text { pulping }\end{array}$} & \multirow{3}{*}{$\begin{array}{l}\text { Caustic soda, } \\
\text { sodium silicate, } \\
\text { hydrogen } \\
\text { peroxide, soap, } \\
\text { etc. }\end{array}$} & \multirow{4}{*}{$\begin{array}{l}\text { Metallic components, sand, glass, plastic, coatings, } \\
\text { fillers, organic compounds from the paints and } \\
\text { printing inks such as 2,4,7,9-Tetramethyl-5-decyne- } \\
\text { 4,7-diol, pulping additive chemicals, compounds } \\
\text { like Si and Ca, higher amounts of organicsi, } \\
\text { thermoplastic resins } s^{j} \text {, TCMTB, chlorophols, etc. } \\
\text { Deinking additives and ink particles, fibers, fines, } \\
\text { fillers, ash, etc. }\end{array}$} & $\begin{array}{l}\text { Newsprint } \\
\text { mill }\end{array}$ & - & 3500 & - & 250 & Color & 1000 (Pt-Co) & \multirow[t]{3}{*}{$\begin{array}{l}{[50,58,71-} \\
76]\end{array}$} \\
\hline & & & & & & $6.2-7.8$ & $3380-4930$ & $1650-2565$ & $1900-3138$ & - & - & \\
\hline & & & & & $\begin{array}{l}\text { Recycled } \\
\text { paper mill }\end{array}$ & 6.36 & 4328 & 669 & 645 & $\begin{array}{l}\text { VFA }^{\mathrm{k}} \\
\text { VSS }^{1}\end{array}$ & $\begin{array}{l}501(\mathrm{mg} / \mathrm{L}) \\
850(\mathrm{mg} / \mathrm{L})\end{array}$ & \\
\hline & RCFs & $\begin{array}{l}\text { De- } \\
\text { inking }\end{array}$ & $\begin{array}{l}\text { Substances like } \\
\mathrm{H}_{2} \mathrm{O}_{2}, \mathrm{NaOH}, \\
\mathrm{Na}_{2} \mathrm{SiO}_{3}, \mathrm{Na}_{2} \mathrm{CO} 3, \\
\text { and other } \\
\text { compounds like } \\
\text { surfactants }\end{array}$ & & $\begin{array}{l}\text { De-inking } \\
\text { effluents }\end{array}$ & $7-8$ & - & - & - & $\begin{array}{l}\text { Moisture } \\
\text { Ash }^{\mathrm{m}}\end{array}$ & $\begin{array}{l}98.7(\%) \\
0.54(\%)\end{array}$ & $\begin{array}{l}{[73,77-} \\
79]\end{array}$ \\
\hline
\end{tabular}

a Total nitrogen.

Total phosphorus.

c Alkaline peroxide MP.

${ }^{d}$ Effluents from seven Canadian mills.

Chlorination and alkaline extraction stages.

f e.g. clay, titanium dioxide, calcium carbonate.

e.g., rosin, starch and styrene copolymers.

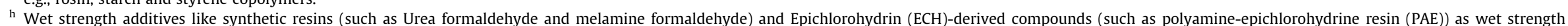
additives.

From light-weight coated paper, because of the coating binders.

${ }^{j}$ In case of laser printing papers.

Volatile fatty acids.

ended solids.

m Ash (after ignition at $900{ }^{\circ} \mathrm{C}$ ) consisted of $\mathrm{SiO}_{2}(16.70 \%), \mathrm{Al}_{2} \mathrm{O}_{3}(16.53 \%), \mathrm{CaO}(22.46 \%), \mathrm{TiO}_{2}(32.39 \%), \mathrm{BaO}(5.43 \%), \mathrm{CuO}(2.59 \%), \mathrm{S}_{2} \mathrm{O}_{3}(1.17 \%), \mathrm{Fe}_{2} \mathrm{O}_{3}(0.92 \%), \mathrm{Na}_{2} \mathrm{O}(0.33 \%)$ 


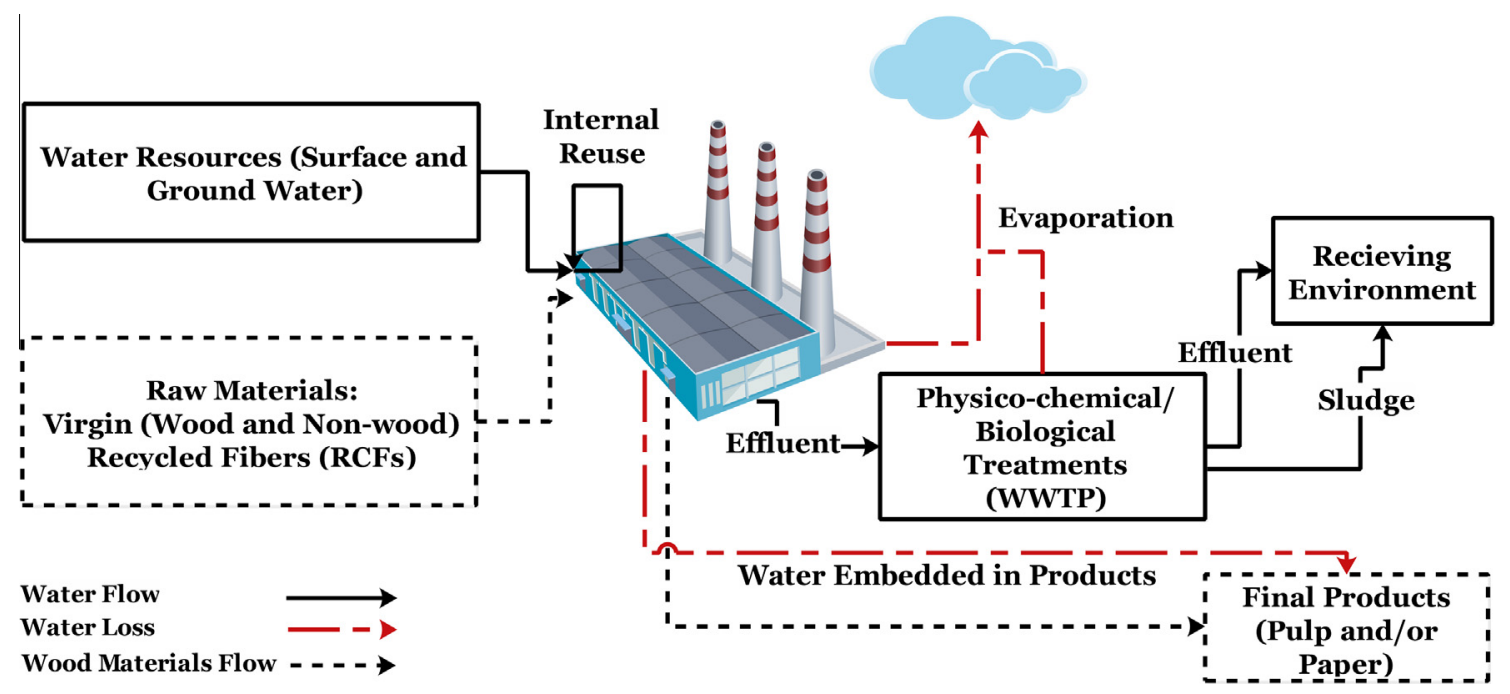

Fig. 3. A schematic of the raw materials flow, use and fate at a typical P\&P mill.

Table 2

Efficiency of physicochemical and biological processes for the treatment of PPMW.

\begin{tabular}{|c|c|c|c|c|c|c|}
\hline \multirow[t]{3}{*}{ Type } & \multirow[t]{3}{*}{ Process } & \multicolumn{4}{|l|}{ Parameters } & \multirow[t]{3}{*}{ References } \\
\hline & & \multirow[t]{2}{*}{ COD removal (\%) } & \multirow[t]{2}{*}{ BOD removal (\%) } & \multicolumn{2}{|c|}{ Other parameters } & \\
\hline & & & & Type & Removal (\%) & \\
\hline \multirow[t]{7}{*}{ Physicochemical } & Electrocoagulation (Al) & 75 & 70 & Lignin & 80 & {$[80]$} \\
\hline & & & & Phenol & 70 & \\
\hline & Flocculation (polydiallyldimethylammonium) & $>90$ & - & Turbidity & $>90$ & [81] \\
\hline & & & & TSS & $>90$ & \\
\hline & Ozonation & $\sim 20$ & - & DOC & $>15$ & [82] \\
\hline & & & & Color & $>50$ & \\
\hline & Fungi + solar photo-Fenton (Cryptococcus $+\mathrm{Fe}^{2+} / \mathrm{H}_{2} \mathrm{O}_{2}$ ) & $>90$ & - & DOC & 90 & [83] \\
\hline \multirow[t]{8}{*}{ Biological } & Fungal (Aspergillus niger) & 60 & - & MTBE extracts & 97 & {$[84]$} \\
\hline & Aerated stabilization basins & 67 & 90 & - & - & [85] \\
\hline & Aeration pond & - & - & 2,4-DCP & $56.0-77.6$ & [86] \\
\hline & Multiple stage activated sludge & 65 & 95 & - & - & [87] \\
\hline & Activated sludge & 76 & - & Color & 76 & [6] \\
\hline & Activated sludge & - & - & Sterols & $>90$ & [88] \\
\hline & Upflow anaerobic filter ${ }^{\mathrm{a}}$ & - & - & AOX & 90.7 & [89] \\
\hline & Modified anaerobic baffled reactor & 71 & 71 & VFA & -32 & [75] \\
\hline
\end{tabular}

a UAF.

flocculant at the optimal conditions (coagulant dosage of $871 \mathrm{mg} / \mathrm{L}$, flocculant dosage of $22.3 \mathrm{mg} / \mathrm{L}$ and $\mathrm{pH} 8.35$ ) recovered $72.7 \%$ of water as a result of the treatment of a PPMW from a primary sedimentation tank.

\subsection{Wastewater and sludge from PEP production processes}

Virgin or RCFs are used as raw materials for the production of P\&P. For this raw materials, a variety of chemical, mechanical or a combination of both methods have been applied so far (Table 1). Chemical additives are used in the several stages of P\&P production process, due to some reasons such as the reduction of the water consumption and saving the energy and raw materials. However, through the recovery of the chemical used for the manufacturing processes of P\&P, the mills are able to reuse a portion of the required chemical raw materials. For instance, the black liquor from bleaching process can be concentrated and burned in order to recover inorganic smelt of $\mathrm{Na}_{2} \mathrm{CO}_{3}$ and $\mathrm{Na}_{2} \mathrm{~S}$ to be re used for cooking the unbleached pulps [47]. However, such strategies would require the infrastructures for the chemical recovery and many of the small and some of medium scale P\&P mills
$(<100 t / d)$ lack of such facilities and, as a result, they discharge the rejects directly into the receiving environment [48]. In addition to the production method applied, the nature and origin of the raw materials used can cause the presence of some toxic and non toxic substances such as resin acids (from conifer species), sterols (mainly $\beta$ sitosterol), waxes, and $\beta$ sitosterol esters (from the Kraft cooking and oxygen pre bleaching of Eucalyptus sp.) in the wastes produced from the P\&P making processes $[21,49]$.

Table 2 presents the results of some recent studies indicating the performance of physicochemical and biological P\&P treatments methods. Various approaches applied for the treatment of PPMW have shown different capabilities to remove the generated pollu tants from the PPMW. However, there are some main drawbacks that have restricted their adoption by the mills. For instance, in spite of the acceptable performance of physico chemical methods for the removal of various wastewater parameters (e.g., chemical oxygen demand (COD), biochemical oxygen demand (BOD), adsorbable organic halogens (AOXs), TSS, and lignin), main limita tions such as to be relatively expensive as well as maintenance requirements besides technical barriers, such as membrane fouling for membrane reactors are restrict their wider applications. 


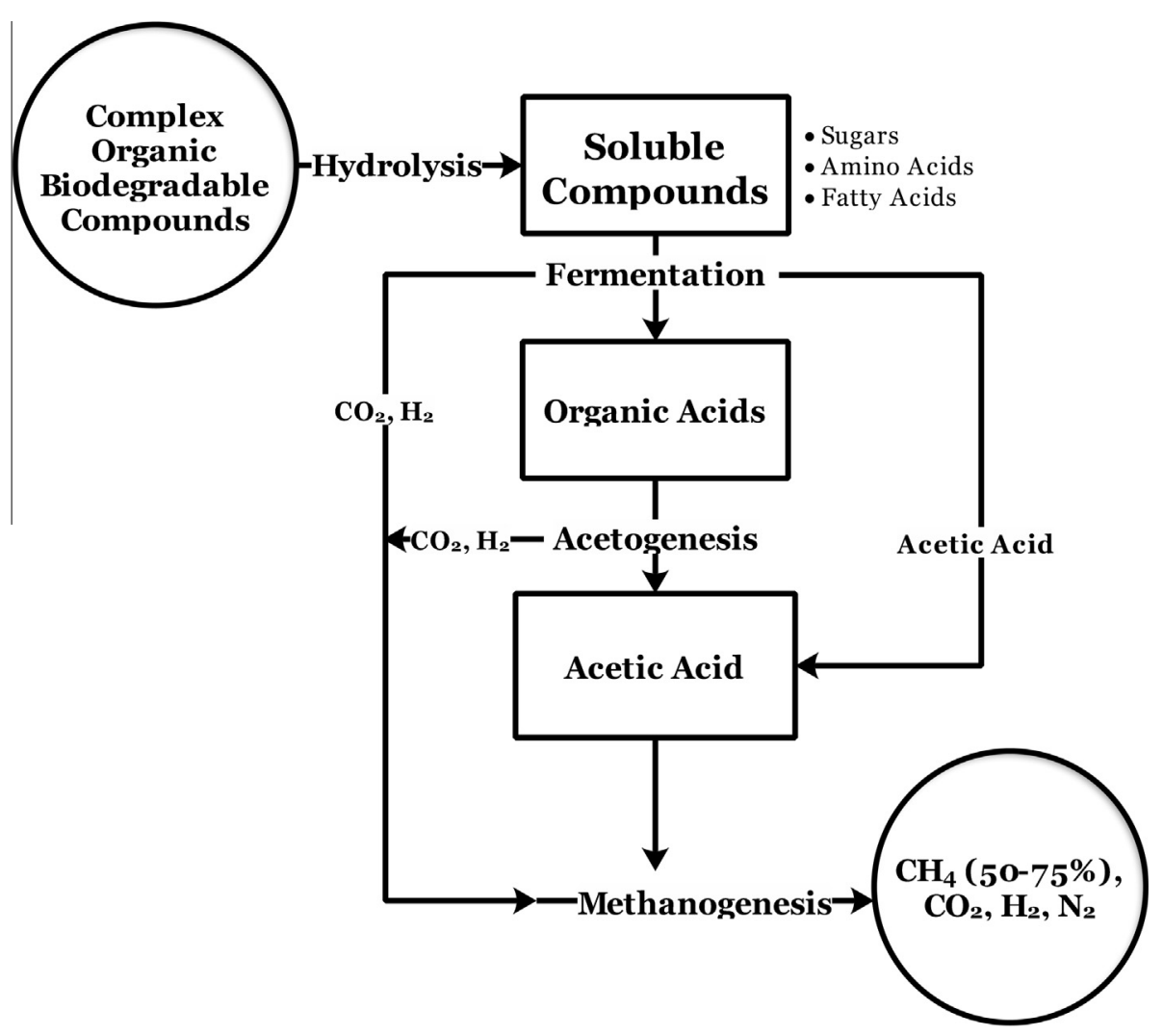

Fig. 4. A schematic of the AD steps.

Biological methods also have shown the feasibility for the treat ment of wastewater from many types of P\&P production processes. Although activated sludge processes are currently the major treatment for P\&P mill effluents, AD has attracted a great amount of attention in recent years due to its inherent merits such as biogas production and minimizing the solid waste production, which has made it an attractive candidate for the treatment of PPMW. However, the toxic effect of some P\&P effluents (e.g., kraft bleaching effluents) for the bacterial communities as well as the sensitivity of the biological systems to the environmental and operational conditions (e.g., restriction of $\mathrm{AD}$ and the fungal activity under high $\mathrm{pH}$ ) are among the main problems of such systems to deal with PPMW. Having this in mind, the optimization of the efficiency of such biological systems is the most important step to achieve the desired performance and facilitation of transferring these technologies from lab scale to full scale applications $[2,50,51]$.

In addition, the treatment of P\&P wastewater normally pro duces a large amount of primary and secondary waste sludge which management and disposal are contributing to about $60 \%$ of the total PPMW treatment cost [52]. The characteristics of the primary and secondary sludge are highly dependent on the raw materials used, on the P\&P production process, and on the applied subsequent wastewater treatment processes. Primary sludge consists mainly of higher size rejects such as fibrous materials (cellulose, hemicellulose and lignin), as well as the rejects from paper making process such as fillers and metallic components, sand, coatings, etc, in the case of paper making from RCFs (Table 1). However, non biodegradable compounds and other rejects from P\&P production processes, based on the efficiency of the applied wastewater treatment processes [50], as well as the biomass from the microbial communities and the cell decay materials are the main constituents of the secondary sludge [53].

\section{Anaerobic digestion of wastewater and sludge}

Hydrolysis, acidogenesis, acetogenesis and methanogenesis are the main steps involved in the AD process (see Fig. 4). Lignocellu losic materials present in P\&P wastes have the potential to slow down the hydrolysis step of the AD process. In addition, anaerobic reactor configuration, operational and environmental conditions (i.e., HRT, pH, temperature), and the presence of inhibitory com pounds like ammonia, sulfide, chlorides, heavy metals, and hardly biodegradable compounds in the wastewater or sludge contents can potentially contribute to slow down the AD process, resulting in a low methane yield and process instability [11]. The factors that critically affect the performance of $A D$ for the treatment of $P \& P$ wastewater and sludge are reviewed and discussed in the next sections.

\subsection{AD of PPM wastewater}

\subsubsection{Reactor configuration}

Among the high rate anaerobic reactors, anaerobic filters (AFs), upflow anaerobic sludge bed reactors (UASBs) and anaerobic mem brane bioreactors (AnMBRs) have been mainly applied to treat the P\&P mill wastewaters.

4.1.1.1. AFs. AFs are earlier types of high rate anaerobic reactors with relatively simple configuration, compared with other types of AD reactors such as fluidized bed reactors (FBRs) and UASB reac tors [90]. Show \& Tay (1999) [91] showed that the texture and the porosity of the media surface can significantly influence the removal of the chemical oxygen demand (COD) by anaerobic filter reactors. In recent years, novel filter media such as sludge fly ash ceramic particles [92], clay ceramic particles [93], and pumice 
stone [94] have been successfully applied in order to improve the AD by using AFs.

However, the application of such systems for the treatment of wastewater from P\&P mills is limited, when compared to reactors with internal settlers, such as UASB reactors. Satyawali, Pant, Singh, \& Srivastava (2009) [95] applied an upflow anaerobic packed bed reactor (UAPBR) with brick ballasts as packing material for the treatment of rayon grade pulp drain effluents. They observed $74.5 \%$ and $81 \%$ reductions in COD and BOD respectively, at an optimum HRT of $12 \mathrm{~h}$. Deshmukh et al. (2009) [89] reported AOX degrada tion from a PPM bleaching effluent by using an AF with upflow. They observed $88 \%$ and $28 \%$ removals of AOX at initial concentra tions of $28 \mathrm{mg} \mathrm{AOX/L}$ and $42 \mathrm{mg}$ AOX/L, respectively, and HRT of 20 days. Bakhshi et al. (2011) [96] studied the removal of phenol from a synthetic wastewater by using a pilot scale UAPBR. Under mesophilic conditions and HRT of $24 \mathrm{~h}$, the maximum biodegrada tion of phenol and biogas production achieved were $98 \%$ and 3.57 L/d, respectively. Jong \& Parry (2003) [97] achieved more than $82 \%$ removal of sulfate from contaminated waters by using a bench scale UAPBR filled with silica sand at an organic and sulfate loading rates of 7.43 , and $3.71 \mathrm{~kg} / \mathrm{d} / \mathrm{m}^{3}$, respectively. Moreover, they observed removals of $\mathrm{Cu}$ and $\mathrm{Zn}>97.5 \%$, removals of $\mathrm{Ni}$ of $77.5 \%$, and removals of As and $\mathrm{Fe}>82 \%$.

The performance of such reactors is mainly impaired by clogging due to the presence of high amounts of suspended solids leading to short circuiting of the wastewater [98]. Although some improvements have been proposed to solve this problem, such as a biological pre treatment [99], further research and developments are critical and necessary, in order to find out technical and economical solutions for this problem.

4.1.1.2. UASBs. Among the several types of anaerobic reactors, UASB has been commonly adopted by pulp and paper industry since 1980 's, due to its advantages when compared with other types of high rate anaerobic reactors, such as low investment requirements [13]. Buzzini \& Pires (2002) [100] reached $80 \%$ on average removal of COD when treating diluted black liquor from a kraft pulp (KP) mill by using an UASB reactor. The performance of a bench scale UASB was also investigated by Buzzini, Gianotti, \& Pires (2005) [101] for the treatment of simulated bleached and unbleached cellulose pulp mill wastewaters. They achieved $76 \%$ on average removal of COD and $7199.7 \%$ on the removal of chlorinated organics. They also observed no inhibitory effect of the chlorinated organics on the removal of COD during the exper iments. Chinnaraj \& Rao (2006) [102] reported $8085 \%$ reduction in COD, while producing $520 \mathrm{~L} / \mathrm{kg}$ COD of biogas, after the replace ment of an anaerobic lagoon by an UASB installation (full scale) for the treatment of an agro based PPMW. Moreover, they achieved a reduction of $6.4 \mathrm{Gg}$ in $\mathrm{CO}_{2}$ emissions through the savings in fossil fuel consumption, and $2.1 \mathrm{Gg}$ reduction in methane emissions from the anaerobic lagoon (equal to $43.8 \mathrm{Gg}$ of $\mathrm{CO}_{2}$ ) in nine months. Zhenhua \& Qiaoyuan (2008) [103] achieved $98 \%$ and $85.3 \%$ reductions in $\mathrm{BOD}_{5}$ and COD, respectively, from pulping effluents by using a combination of UASB and sequencing batch reactors (SBRs), while the removal efficiency when the substrate was just treated by a UASB reactor was considered to be $95 \%$ and $75 \%$ for $\mathrm{BOD}_{5}$ and COD, respectively at an HRT of 1 day. Rao \& Bapat (2006) [104] achieved $7075 \%$ and $8590 \%$ reductions of $C O D$ and $B O D$, respectively, and a methane yield of $0.310 .33 \mathrm{~m}^{3} / \mathrm{kg}$ of COD reduced, when using a full scale UASB for treating the pre hydrolysate liquor from a rayon grade pulp mill. Puyol, Mohedano, Sanz, \& Rodríguez (2009) [105] studied the effective removal of 2,4 DCP by using both UASB and anaerobic expanded granular sludge bed reactor (EGSB). Moreover, they indicate that EGSB reactor exhibited a better efficiency for the removal of both COD and 2,4 DCP (75\% and 84\%, respectively), when compared with UASB reactor (61\% and $80 \%$, respectively), at loading rates of $1.9 \mathrm{~g} \mathrm{COD} / \mathrm{L} / \mathrm{d}$ and $100 \mathrm{mg} \mathrm{2,4} \mathrm{DCP/L/d.}$

4.1.1.3. AnMBRs. In recent years, AnMBRs which combine the advantages of $\mathrm{AD}$ process and membrane separation mechanisms have received considerable attention due to their advantages for wastewater treatment such as lower sludge production and energy requirements over conventional anaerobic treatment methods [106]. By adopting anaerobic membrane technologies, it is possible to achieve complete solid liquid phase separation and, as a result, complete biomass retention [107]. Since 1990 s, some studies have been carried out to investigate the efficiency of such systems for the treatment of PPMW, and have shown 50 96\% removal of COD [108]. Xie et al. (2010) [109] investigated the performance of a submerged anaerobic membrane bioreactors (SAnMBRs) for the treatment of kraft evaporator condensate at mesophilic condi tions. They reached 93 99\% COD removal under an OLR of $124 \mathrm{~kg}$ $\mathrm{COD} / \mathrm{m}^{3} /$ day. Moreover, the methane production rate was observed to be $0.35 \pm 0.05 \mathrm{~L} / \mathrm{g}$ COD reduced. Lin et al. (2009) [110] achieved 97 99\% COD removal from a kraft evaporator con densate at a feed COD of $10,000 \mathrm{mg} / \mathrm{L}$ in two pilot scale (ther mophilic and mesophilic) submerged AnMBRs. Gao, Lin, Leung, \& Liao (2010) [111] observed about 90\% COD removal during the steady period (22nd 33rd day) of the performance of a submerged AnMBR, treating thermomechanical pulping (TMP) whitewater.

Several types of membranes such as PVDF based membranes [112], hollow polymeric fibers [113], ceramic tubular [114], etc. have been so far developed for the treatment of the various types of wastewaters. However, flat sheets of polyvinylidine fluoride (PVDF), as a flexible, low weight, inexpensive, and highly non reactive material, are the dominant membranes used for the treat ment of P\&P mill effluents such as Kraft evaporator condensate [110] and TMP whitewater [111], as internal configurations. The maintenance and operational costs arising from membrane fouling and the frequent cleaning requirement of such hydrophobic poly meric membranes as well as being relatively energy intensive are nevertheless considered the main obstacles of such treatment sys tems dealing with various types of wastewaters. After studying the fouling mechanisms in AnMBRs, Charfi, Ben Amar, \& Harmand (2012) [115] concluded that the cake formation is the main mech anism responsible for membrane fouling in AnMBRs. Such findings were also corroborated by other studies [110]. Although some measures such as feed pre treatment, optimization of operational conditions, broth properties improvements, and membrane clean ing have already been applied to control the membrane fouling process [14], this issue demands further studies to enhance AnMBR performance.

4.1.1.4. Other types of $A D$ reactors. The application of other types of anaerobic reactors has also been investigated for the treatment of PPMW, although the number of such studies is scarce in the liter ature. For instance, Grover, Marwaha, \& Kennedy (1999) [116] achieved a maximum of $60 \%$ COD removal from black liquor treat ment by using an anaerobic baffled reactor (ABR) at an organic loading rate (OLR) of $5 \mathrm{~kg} / \mathrm{m}^{3 / \mathrm{d}}$, a HRT of $2 \mathrm{~d}$, a pH 8.0 and a tem perature of $35^{\circ} \mathrm{C}$.

Table 3 summarizes the performance of various reactor config urations for the anaerobic treatment of PPMWs.

\subsubsection{Operating conditions}

4.1.2.1. HRT. HRT is one of the most significant influencing factors that can potentially affect the performance of an anaerobic reactor. In UASB reactors type, at high HRTs, the upflow velocity $\left(\mathrm{V}_{\mathrm{up}}\right)$ decreases, and, as a result, the efficiency of the reactor for the removal of the suspended solids increases [119]. Moreover, ele vated HRT can enhance the COD removal through the elevation 
Table 3

Performance of various reactor configurations for the anaerobic treatment of PPMWs.

\begin{tabular}{|c|c|c|c|c|c|c|c|}
\hline \multirow[t]{3}{*}{ Reactor configuration } & \multirow[t]{3}{*}{ Effluents origin } & \multicolumn{5}{|l|}{ Parameters } & \multirow[t]{3}{*}{ References } \\
\hline & & \multicolumn{2}{|l|}{ COD } & \multicolumn{3}{|c|}{ Other parameters } & \\
\hline & & $\begin{array}{l}\text { Initial } \\
(\mathrm{mg} / \mathrm{L})\end{array}$ & $\begin{array}{l}\text { Removal } \\
(\%)\end{array}$ & $\begin{array}{l}\text { Parameter/ } \\
\text { substance }\end{array}$ & $\begin{array}{l}\text { Initial } \\
(\mathrm{mg} / \mathrm{L})\end{array}$ & $\begin{array}{l}\text { Removal } \\
(\%)\end{array}$ & \\
\hline \multirow{3}{*}{$\begin{array}{l}\text { UAPBR, (brick ballasts } \\
\text { as packing material) }\end{array}$} & \multirow[t]{3}{*}{ Rayon grade pulp drain effluent } & \multirow[t]{3}{*}{$3200^{\mathrm{a}}$} & \multirow[t]{3}{*}{74.5} & BOD & - & 81 & \multirow[t]{3}{*}{ [95] } \\
\hline & & & & $\mathrm{TSS}^{\mathrm{b}}$ & - & 62.7 & \\
\hline & & & & TDS $^{\mathrm{c}}$ & - & 52 & \\
\hline \multirow[t]{2}{*}{ UAF } & \multirow[t]{2}{*}{ Bleach composite wastewater } & \multirow[t]{2}{*}{-} & \multirow[t]{2}{*}{-} & AOX & 28 & 88 & \multirow[t]{2}{*}{ [89] } \\
\hline & & & & AOX & 42 & 28 & \\
\hline UAPBR & Synthetic phenolic wastewater & - & - & Phenol & 1000 & 98 & [96] \\
\hline \multirow{6}{*}{$\begin{array}{l}\text { UAPBR, filled with } \\
\text { silica sand }\end{array}$} & \multirow[t]{6}{*}{-} & & \multirow[t]{6}{*}{-} & Sulfate & 2280 & 82 & \multirow[t]{6}{*}{ [97] } \\
\hline & & \multirow[t]{5}{*}{-} & & $\mathrm{Cu}$ & 10.8 & $>97.5$ & \\
\hline & & & & $\mathrm{Zn}$ & 10.3 & $>97.5$ & \\
\hline & & & & $\mathrm{Ni}$ & 9.5 & 82 & \\
\hline & & & & As & 10.6 & 82 & \\
\hline & & & & $\mathrm{Fe}$ & 11.6 & 82 & \\
\hline UASB & Diluted black liquor & 1400 & $76-86$ & - & - & - & {$[100]$} \\
\hline UASB & Diluted black liquor & 1400 & 76 & $\begin{array}{l}\text { Chlorinated } \\
\text { organics }\end{array}$ & 15 & 71-99.7 & [101] \\
\hline \multirow[t]{3}{*}{ UASB } & \multirow[t]{3}{*}{ Bagasse-based P\&P mill } & \multirow[t]{3}{*}{$2000-7000$} & \multirow[t]{3}{*}{$80-85$} & - & - & - & \multirow[t]{3}{*}{ [102] } \\
\hline & & & & VFA & $500-3500$ & - & \\
\hline & & & & SS & $400-1000$ & & \\
\hline $\mathrm{UASB}+\mathrm{SBR}$ & Wheat straw explosion pulping effluent & - & 85.3 & $\mathrm{BOD}_{5}$ & - & 98 & [103] \\
\hline & & - & 75 & $\mathrm{BOD}_{5}$ & - & 95 & \\
\hline UASB & Synthetic wastewater containing 2,4-DCP & 1900 & 61 & 2,4-DCP & 100 (mg/L/day) & 80 & {$[105]$} \\
\hline EGSB & Synthetic wastewater containing $2,4-\mathrm{DCP}$ & 1900 & 75 & 2,4-DCP & 100 (mg/L/day) & 84 & \\
\hline UASB & $\begin{array}{l}\text { Pre-hydrolysate liquor from a rayon grade } \\
\text { pulp mill }\end{array}$ & 2500 & $70-75^{\mathrm{d}}$ & BOD & - & $85-90$ & {$[104]$} \\
\hline UASB & P\&P mill & $1,133.9 \pm 676$ & $\sim 81$ & TSS & $1,063 \pm 537$ & $\sim 67$ & {$[117]$} \\
\hline & & & & VFA & $397 \pm 347.7$ & $\sim 87$ & \\
\hline $\mathrm{SGBR}^{\mathrm{e}}$ & P\&P mill & $1,133.9 \pm 676$ & $\sim 82$ & TSS & $1,063 \pm 537$ & $\sim 57$ & [117] \\
\hline & & & & VFA & $397 \pm 347.7$ & $\sim 53$ & \\
\hline Submerged AnMBR & Kraft evaporator condensate & $2500-2700$ & 93-99 & - & - & - & [109] \\
\hline Submerged AnMBR & Kraft evaporator condensate & 10,000 & $97-99$ & - & - & - & {$[110]$} \\
\hline Submerged AnMBR & TMP whitewater & $2782-3350$ & 90 & - & - & - & [111] \\
\hline $\mathrm{ABR}$ & Cornstalk fibrous pulp wastewater & 4000 & $81.9^{\mathrm{f}}$ & - & - & - & [118] \\
\hline ABR & Cornstalk fibrous pulp wastewater & 4002 & $81.1^{\mathrm{g}}$ & - & - & - & \\
\hline & & 6560 & $75.7^{g}$ & - & - & - & [118] \\
\hline ABR & Black liquor & $10,003 \pm 69$ & 60 & - & - & - & [116] \\
\hline ABR & Recycled paper mill effluents & $3380-4930$ & Up to 71 & BOD & $1650-2565$ & $\sim 70$ & [75] \\
\hline & & & & VFA & $455-490$ & $\sim-31$ & \\
\hline & & & & TSS & $1900-3138$ & $\sim 45$ & \\
\hline
\end{tabular}

a The rate of the effluent generation was $6000-7000 \mathrm{~m}^{3} /$ day.

b Total dissolved solids.

c Total suspended solids.

${ }^{\mathrm{d}}$ Full-scale installation with an optimum OLR of 10 and a methane yield of $0.31-0.33 \mathrm{~m}^{3} / \mathrm{kg}$ of COD reduced.

e Static granular bed reactor.

f HRT $18 \mathrm{~h}$.

g HRT $24 \mathrm{~h}$.

of the contact time. Parker, Hall, \& Farquhar (1993) [120] reported 27 65\% removal of adsorbable organic halogens (AOX) when treat ing a kraft mill bleach wastewater by using a UASB reactor, depending on the HRT ( $348 \mathrm{~h}$ ). Since then, the developments on the design and operational conditions of high rate reactors have led them to treat P\&P mill wastes more efficiently. Turkdogan et al. (2013) [117] achieved 60\% and $81 \%$ removals of COD by using a pilot scale UASB reactor at 4 and 9 h HRT, respectively. Moreover, they observed that the performance of a static granular bed reactor (SGBR) was better than that of a UASB reactor, with more than $70 \%$ COD removal at $4 \mathrm{~h}$ HRT. In addition, at $24 \mathrm{~h}$ HRT, the suspended solids removal was observed to be slightly higher in the SGBR. Sun et al. (2009) [118] investigated the effect of different HRTs on the performance of an ABR when treating the cornstalk fibrous pulp wastewater. They observed that with the initial COD of $4000 \mathrm{mg} / \mathrm{L}$, when HRT decreased from $40 \mathrm{~h}$ to $19 \mathrm{~h}$, the COD removal efficiency decreased from $81.9 \%$ to $75.7 \%$, respectively. The performance of $\mathrm{AD}$ systems under various HRTs may also be affected by the operating temperature. Ahn \& Forster (2002) [121] stated that with an increase in the HRT from 11.7 to $26.2 \mathrm{~h}$, the performance of the thermophilic digestion increases, while no significant HRT related improvement in the mesophilic digester is observed in terms of COD removal when treating a simulated paper mill wastewater.

The presence of 2,4 dichlorophenol (2,4 DCP) can negatively affect the methanogenic phase [105]. Sponza \& Uluköy (2008) [122] evaluated the removal of 2,4 DCP and COD from a synthetic wastewater at different HRTs ranging from 2 to $20 \mathrm{~h}$ using an UASB reactor. They observed a decrease in the COD removal from $83 \%$ to $65 \%$ when the HRT was decreased from 20 to $2 \mathrm{~h}$. In these conditions, the removal of 2,4 DCP was $99 \%$ and $83 \%$, respec tively. Sponza \& Cigal (2008) [123] identified Methanobacterium bryantii, Methanobacterium formicicum, Methanobrevibacter smithii, Methanococcus voltae, Methanosarcina mazei, Methanosarcina ace tivorans, Methanogenium bourgense, and Methanospirillum hungatei as the microorganisms involved in the treatment of 2,4 DCP, when 
Table 4

The effect of HRT on the performance of AD for the treatment of PPMWs.

\begin{tabular}{|c|c|c|c|c|c|c|c|c|}
\hline \multirow[t]{3}{*}{ Reactor } & \multirow[t]{3}{*}{ Effluents origin } & \multicolumn{6}{|l|}{ Parameters } & \multirow[t]{3}{*}{ References } \\
\hline & & \multicolumn{3}{|l|}{ COD } & \multicolumn{3}{|c|}{ Other parameters } & \\
\hline & & Initial (mg/L) & Removal (\%) & HRT (h) & Parameters & Initial (mg/L) & Removal (\%) & \\
\hline \multirow[t]{3}{*}{ UASB } & \multirow[t]{3}{*}{ Black liquor } & \multirow[t]{3}{*}{1400} & \multirow[t]{3}{*}{76} & \multirow[t]{3}{*}{24} & BOD & 800 & - & \multirow[t]{3}{*}[100]{} \\
\hline & & & & & Sulfide & 8.8 & - & \\
\hline & & & & & $P_{\text {total }}$ & 6.5 & - & \\
\hline \multirow[t]{4}{*}{ UASB } & \multirow[t]{4}{*}{ Black liquor } & 1400 & 86 & 14.4 & - & - & - & \multirow[t]{4}{*}[124]{} \\
\hline & & \multirow[t]{3}{*}{1400} & \multirow[t]{3}{*}{75} & \multirow[t]{3}{*}{24} & BOD & 660 & - & \\
\hline & & & & & $\mathrm{P}_{\text {total }}$ & 4.0 & - & \\
\hline & & & & & VFA & - & 30 & \\
\hline UASB & Black liquor & 1400 & 78 & 30 & VFA & - & 29 & \\
\hline \multirow[t]{2}{*}{ UASB } & \multirow[t]{2}{*}{ Synthetic effluents } & 514 & 83 & 20 & $2,4 \mathrm{DCP}^{\mathrm{a}}$ & 12 & 99 & \multirow[t]{2}{*}[122]{} \\
\hline & & 2000 & 65 & 2 & $2,4 \mathrm{DCP}$ & 232 & 83 & \\
\hline \multirow[t]{2}{*}{ UASB } & \multirow[t]{2}{*}{ Segregated kraft bleaching effluents } & - & - & 3 & AOX & - & 27 & \multirow[t]{2}{*}{ [120] } \\
\hline & & - & - & 48 & AOX & - & 65 & \\
\hline \multirow[t]{6}{*}{ UASB } & \multirow[t]{6}{*}{ TMP paper mill wastewater } & \multirow[t]{2}{*}{$1,133.9$} & \multirow[t]{2}{*}{60} & \multirow[t]{2}{*}{4} & TSS & 1,063 & 92 & \multirow[t]{6}{*}{ [117] } \\
\hline & & & & & VFA & 397 & 71 & \\
\hline & & \multirow[t]{2}{*}{$1,133.9$} & 85 & 9 & TSS & 1,063 & 55.57 & \\
\hline & & & & & VFA & 397 & 84 & \\
\hline & & $1,133.9$ & 81 & 24 & TSS & 1,063 & 50 & \\
\hline & & & & & VFA & 397 & 88 & \\
\hline ABR & Cornstalk fibrous pulp wastewater & 4000 & 81.9 & 40 & - & - & - & [118] \\
\hline & & & 75.7 & 19 & - & - & - & \\
\hline $\mathrm{AF}^{\mathrm{a}}$ & Simulated paper mill wastewater & & 85 & 13 & - & - & - & [121] \\
\hline & & & $>90$ & 23 & - & - & - & \\
\hline MAHB $^{\mathrm{b}}$ & RCFs & $1000-4000$ & 97.69 & $-{ }^{c}$ & VFA & $35^{\mathrm{d}}$ & - & [125] \\
\hline & & & 78.37 & $-{ }^{e}$ & VFA & $\sim 10^{\mathrm{f}}$ & - & \\
\hline
\end{tabular}

\footnotetext{
a Thermophilic conditions $\left(55^{\circ} \mathrm{C}\right)$.

b Anaerobic hybrid baffled.

c OLR of $1.33 \mathrm{gm} \mathrm{COD/lit/day.}$

d VFA concentration at OLR of $2.00 \mathrm{gm} \mathrm{COD/lit/day.}$

e OLR of $2.00 \mathrm{gm}$ COD/lit/day.

${ }^{\mathrm{f}}$ VFA concentration at OLR of $1.33 \mathrm{gm} \mathrm{COD} /$ lit/day.
}

Table 5

Optimal conditions for the growth of some methanogenic bacteria $[15,139,144]$.

\begin{tabular}{lll}
\hline Genus & Optimal temperature range & Optimal pH range \\
\hline Methanobacterium & $37-45$ & $6.9-7.2$ (Methanobacterium bryantii) \\
Methanobrevibacter & $37-40$ & $7.8-8$ (Methanobrevibacter arboriphilus) \\
& & $\sim 7$ (Methanobrevibacter smithii) \\
Methanosphaera & $35-40$ & $\sim 7$ \\
Methanolobus & $35-40$ & $\sim 7$ \\
Methanococcus & $35-40$ & $5-7$ (Methanococcus voltae) \\
Methanosarcina & $30-40$ & $6.5-7.5$ (Methanosarcina acetivorans) \\
Methanocorpusculum & $30-40$ & $6.4-7.2$ (Methanocorpusculum aggregans) \\
Methanoculleus & $35-40$ & $\sim 7$ \\
Methanogenium & $20-40$ & $6.2-6.6$ (Methanogenium cariaci) \\
Methanoplanus & $30-40$ & $6.6-7.2$ (Methanoplanus endosymbiosus) \\
Methanospirillum & $35-40$ & - \\
Methanococcoides & $30-35$ & $\sim 7$ \\
Methanolobus & $35-40$ & $\sim 7$ \\
Methanohalophilus & $35-45$ & $\sim 7$ \\
Methanohalobium & $50-55$ & $\sim 7$ \\
Methanosarcina & $50-55$ & $6.5-7.5$ (Methanosarcina acetivorans) \\
\hline
\end{tabular}

using a UASB reactor. Table 4 presents the results from some studies investigating the effects of the HRT on the performance of anaerobic reactors for the treatment of PPMW.

\subsubsection{Environmental conditions.}

4.1.2.2.1. Temperature. The operating temperature is a significant variable that can potentially affect the efficiency of the COD removal and biogas production from various wastewaters through, for instance, an increase in the microbiological activity [126]. This process is generally carried out at mesophilic conditions (35 $37^{\circ} \mathrm{C}$ ). However, several studies on the AD of various sub strates have clearly indicated that the thermophilic conditions allow a better COD removal and biogas production [127].
Moreover, benefits like higher maximum specific growth rate of microorganisms $\left(\mu_{\max }\right)$, and therefore better organic matter degradation in a shorter operating time [126], higher colour removal efficiency [128], more favorable disinfection capability, improved AD steady state stability [129], and being more feasible for co digestion approaches than mesophilic processes [130] can be expected by operating under thermophilic conditions.

Yilmaz et al. (2008) [90] studied the performance of two AFs under mesophilic $\left(35^{\circ} \mathrm{C}\right)$ and thermophilic $\left(55^{\circ} \mathrm{C}\right)$ conditions for the treatment of a paper mill wastewater. They observed no significant differences at OLRs up to $8.4 \mathrm{~g} \mathrm{COD} / \mathrm{L} / \mathrm{d}$. At higher OLRs, slightly better COD removal and biogas production were observed in the thermophilic reactor, which also denotes the effect of the 
OLR on the performance of the AD process. Ahn \& Forster (2002) [121] showed that the specific methane production obtained in an AF treating a simulated paper mill wastewater under thermophilic digestion was higher than the one obtained at a mesophilic temperature under all the studied HRTs from 11.7 to $26.2 \mathrm{~h}$. In the same study, they also indicated that the performance of the two mesophilic and thermophilic upflow AFs treating a simulated paper mill wastewater can be affected either by a drop or an increase in the operating temperature. They showed that the performance of both digesters, in terms of COD removal effi ciency and biogas production at an OLR of $1.95 \mathrm{~kg} \mathrm{COD} / \mathrm{m}^{3} /$ day, was negatively affected by a drop in the operating temperature to $1824^{\circ} \mathrm{C}$ and to $35^{\circ} \mathrm{C}$ for mesophilic and thermophilic digesters, respectively. When the temperature was increased to 55 and $65{ }^{\circ} \mathrm{C}$ in mesophilic and thermophilic digesters, respectively, they also observed an immediate decrease in the treatment efficiency [131]. However, some studies have also shown that anaerobic bio mass have a potential for good recovery after undergoing thermal shock [100]. The effect of the variations in the operating tempera ture can be significantly affected by the configuration of the reac tor. SAnMBR seems to be more resistant to temperature variation when compared with other high rate conventional anaerobic digesters. Lin et al. (2009) [110] observed no significant difference between the thermophilic and mesophilic AD, when treating pulp ing wastewater by using a pilot scale SAnMBR. They also observed that the mesophilic SAnMBR can exhibit a better filtration perfor mance in terms of filtration resistance. Gao et al. (2011) [107] investigated the effect of the temperature and temperature shock on the performance of a SAnMBR treating TMP pressate. Their results indicated that the COD removal at 37 and $45^{\circ} \mathrm{C}$ was slightly higher than that at $55^{\circ} \mathrm{C}$. However, they observed no significant differences between the methane productions at the various tem peratures. They also indicated that temperature shock can affect the diversity and richness of the species. A COD removal efficiency of $9799 \%$ was observed at a feed COD of $10,000 \mathrm{mg} / \mathrm{L}$ in both SAnMBRs.

In spite of the advantages of conventional mesophilic and ther mophilic treatments, low temperature $\mathrm{AD}$ has emerged in recent years, as an economic method to deal with cool, dilute effluents which were considered as inappropriate substrates for AD [132]. McKeown, Hughes, Collins, Mahony, \& O'Flaherty (2012) [133], by reviewing the basis and the performance of the low temperature $\mathrm{AD}$ for wastewater treatment, concluded that the adoption of effective post treatments for low temperature anaero bic digestion (LTAD) is a way to satisfy the stringent environmental regulations. Some recent studies have also indicated that LTAD can be more efficient by adopting the co digestion approach (in pilot scale application) [134]. However, significant physical, chemical and biological improvements should be applied to high rate AD under low temperature conditions to enhance the efficiency of the present $\mathrm{AD}$ systems, and to improve the amount of the methane produced during the related anaerobic processes.

4.1.2.2.2. $\mathrm{pH}$. The anaerobic digesters are very sensitive to changes in the $\mathrm{pH}$ of the system. This occurs mainly due to the restriction of the methanogens growth below pH 6.6 [135] (Table 5). Methano gens are more sensitive to $\mathrm{pH}$, compared to fermentative microorganisms which can survive in a wider $\mathrm{pH}$ range between 4.0 and 8.5 [136]. By inhibiting the methanogens, VFAs are pro duced and converted to acetic acid, hydrogen and carbon dioxide and thus they are accumulated in the medium. As a result, the $\mathrm{pH}$ will decrease leading to a further inhibition of the microbial activities [137]. Allowing methanogens to be reproduced by stop ping the substrate feeding is considered to be one of the possible ways [15] In order to correct the $\mathrm{pH}$ failure. Moreover, co digestion of the main substrate with an appropriate ratio of another (co)substrate is an applicable way to provide the system

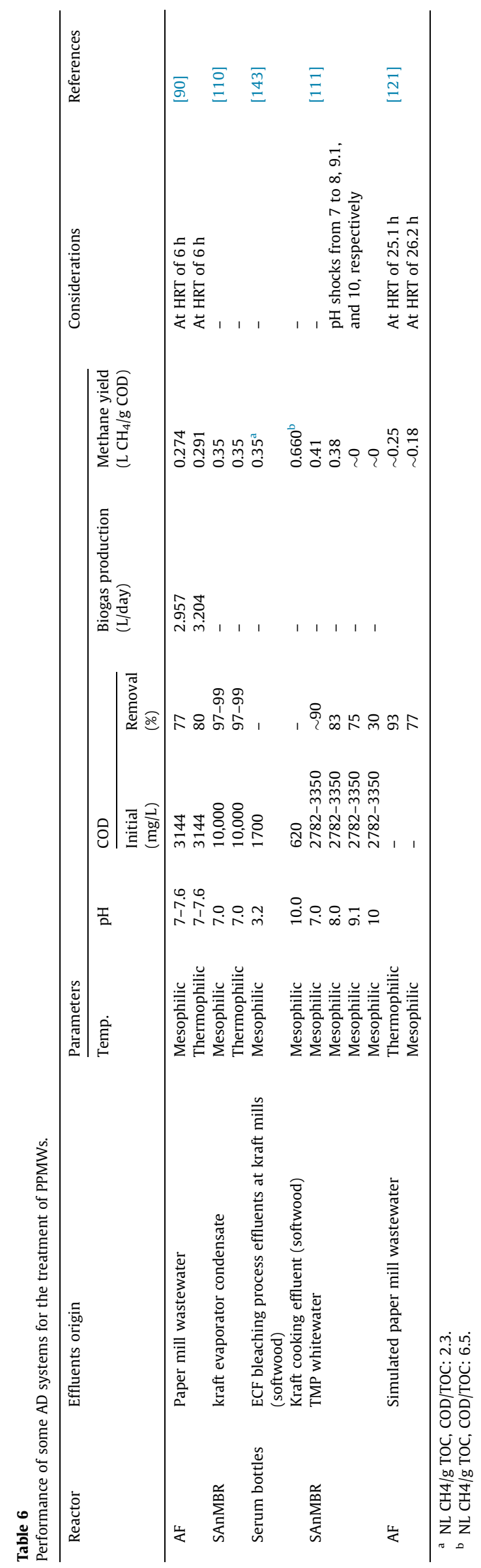


Table 7

AD performance with physico-chemical methods for pre-treatment of PPMWs.

\begin{tabular}{|c|c|c|c|c|c|c|}
\hline \multirow[t]{3}{*}{ Wastewater } & \multirow[t]{3}{*}{ Pre-treatment method } & \multicolumn{4}{|l|}{ Parameters } & \multirow[t]{3}{*}{ References } \\
\hline & & \multicolumn{2}{|l|}{ COD } & \multicolumn{2}{|c|}{ Biodegradability } & \\
\hline & & Initial (mg/L) & Removal (\%) & Initial & Final & \\
\hline Bleaching effluent & Precipitation & 1510 & Up to 90 & 0.11 & 0.26 & [153] \\
\hline Blending black liquor & Coagulation + Flocculation & 1358 & - & - & - & {$[46]$} \\
\hline Synthetic wastewater & Electrocoagulation & 2500 & $\sim 95$ & - & - & [154] \\
\hline Effluents from equalization tank & Flocculation & $2900 \pm 90$ & $>90$ & - & - & [81] \\
\hline Cardboard industry wastewater & Flocculation & $500-1800$ & $>80$ & - & - & [155] \\
\hline Effluents from aerated lagoons & Electrocoagulation & 426 & 75 & - & - & [81] \\
\hline TCF effluents & Fungi-solar photo-Fenton & 1802 & $>90$ & - & - & [83] \\
\hline
\end{tabular}

with a suitable $\mathrm{pH}$, and to increase its buffering capacity [138]. However, the most appropriate $\mathrm{pH}$ range for such reactors is between 6 and 8 [139]. The variation in the $\mathrm{pH}$ can also influence the activities of the microorganisms including metabolism and degrading efficiency of the system [140]. Moreover, the morphol ogy of the bacterial communities may be influenced by the changes in the pH. Sandberg \& Ahring (1992) [141] stated that disintegra tion of microbial granules can be expected at alkaline $\mathrm{pH}$ values. This is a very important issue because the kraft wood pulping efflu ent is alkaline [142] which may lead to the failure of the system. Moreover, the ECF acidic effluents from the KP mills have been shown to be very toxic to the AD microorganisms [143] and this can directly affect the methane production from such effluents. Gao et al. (2010) [111] indicated that although a pH shock of 8.0 had no important adverse effects on the performance of a SAnMBR in terms of COD removal, biogas production and membrane filtra tion, the long lasting negative effects of $\mathrm{pH}$ shocks of 9.1 and 10.0 were significant. They also observed that after providing the nor mal $\mathrm{pH}$ (7.0), it took approximately 30 days for the total recovery of the reactor performance after the $\mathrm{pH}$ shock of 10 , compared with 1 , and 6 days for $\mathrm{pH}$ shocks of 8.0 and 9.1, respectively.

Table 6 presents the results of some studies on the performance of $\mathrm{AD}$ under various operating conditions, especially temperature and $\mathrm{pH}$, for the treatment of PPMWs.

\subsubsection{Inhibitory elements}

The efficiency of an AD system may be limited by the presence of some elements. Relatively high amounts of soluble forms of nitrogen and phosphorous are required to ensure the sufficient growth and activity of all microorganisms, involved in all $A D$ stages. This is considered a significant feature for the treatment of PPMW, due to the low amount of nitrogen, as a key nutrient, which normally occurs in such type of residues [145]. In addition, the ratio of key elements is of high importance to avoid the failure of the AD process. Bouallagui (2003) [146] applied an optimum ratio of 100 130:4:1 for COD:N:P, as an optimal condition for AD of vegetable biomasses. Qu et al. (2012) [61] reported the adjust ment of this ratio to $100: 5: 1$ for appropriate biomass growth. The successful adoption of this ratio has been also indicated by other studies [121]. Furthermore, the ratio of carbon to nitrogen $(\mathrm{C}: \mathrm{N})$ is of importance to ensure the desirable efficiency of an AD system. In this regard, a low $\mathrm{C}: \mathrm{N}$ ratio may cause the accumulation of total ammonia nitrogen or VFAs, which are inhibitor factors for AD performance. Moreover, the inhibition of the methane produc tion is considered to be a result of a high C: $\mathrm{N}$ ratio, through the rapid consumption of the nitrogen by methanogens. The optimal amount of 25:1 has been determined for C:N [147].

In addition, the PPMW often contains high amounts of sulfide compounds which may inhibit the AD process. Air purging is considered an effective way to increase the efficiency of the system and to remove the adverse toxic effects caused by sulfide compounds. Lin et al. (2014) [148] achieved a considerable improvement in the COD removal (from $2030 \%$ to $6575 \%$ ) by using a UAPBR anaerobic digester, when a foul condensate from a PPI was purged with air for at least $2 \mathrm{~h}$ before the pre digestion stage. Zhou, Imai, Ukita, Li, \& Yuasa (2007) [149] achieved a 40\% increase (from $40 \%$ to $80 \%$ ) in the removal of COD from a sulfite pulp mill evaporator condensate, by applying a direct limited aeration in the UASB, at an OLR of $8 \mathrm{~kg} \mathrm{COD} \mathrm{m}^{3} / \mathrm{d}$ and a HRT of $12 \mathrm{~h}$. This extra COD removal occurred due to sulfide oxidation and $\mathrm{H}_{2} \mathrm{~S}$ removal, which can lead to the methanogens improvements.

\subsubsection{Pre treatment strategies}

Although many attempts have been made to enhance the removal of the persistent pollutants from PPMWs (Table 7), the number of published papers investigating the direct effects of the physico chemical and biological pre treatments on the perfor mance of AD facilities is still scarce. Kim, Yeom, Ryu, \& Song (2004) [150] achieved $60 \%$ removal of the calcium hardness in the $\mathrm{CO}_{2}$ stripper when a UASB/CO 2 stripper system was used for the treatment of liner paper wastewater. In this situation, more than $60 \%$ removal efficiency for the anaerobic process of COD was also observed. Yue, Li, \& Yu (2013) [151] by reviewing the performance of the rumen microorganisms for $\mathrm{AD}$ of lignocellulosic biomass showed the higher hydrolytic and acidogenic activity of such microbial inoculums, compared to other microorganisms. Yuan et al. (2012) [152] indicated that pre treatment of the filter paper, office paper, newspaper, and cardboard with a microbial consor tium, containing Clostridium straminisolvens CSK1 and Clostridium $\mathrm{sp}$, resulted in a significant increase in the soluble chemical oxygen demand (SCOD) and, as a consequence, an improvement in the methane production with all studied substrates. Baba, Tada, Fukuda, \& Nakai (2013) [153] achieved a 2.6 times higher methane production $(73.4 \%$ of the theoretical methane yield), when the waste paper was soaked with rumen fluid for $6 \mathrm{~h}$ at $37^{\circ} \mathrm{C}$ before treatment in a semi continuous $\mathrm{AD}$, compared to that of untreated paper.

\subsubsection{Anaerobic aerobic combinations}

According to most references [51] a system consisting of an anaerobic followed by an aerobic process is a better option for the removal of COD, AOX and colour from P\&P mill streams. Tezel, Guven, Erguder, \& Demirer (2001) [156] observed 91\% and 58\% removals of COD and AOX, respectively, by using sequential anaer obic and aerobic digestion systems to treat a PPMW, at a HRT of $5 \mathrm{~h}$ and $6.54 \mathrm{~h}$ for the anaerobic and aerobic processes, respectively. Bishnoi, Khumukcham, \& Kumar (2006) [157] achieved a maxi mum methane production up to $430 \mathrm{~mL} /$ day. Moreover, a COD removal up to $64 \%$ was obtained, while VFAs increased up to $54 \%$ at a $\mathrm{pH}$ of 7.3 , a temperature of $37^{\circ} \mathrm{C}$ and 8 days HRT during AD. Afterwards, COD and BOD removals were $81 \%$ and $86 \%$, respec tively, at $72 \mathrm{~h}$ HRT in activated sludge process.

It also seems that a combination of fungal and bacterial strains can help for a more effective removal of recalcitrant pollutants from streams. For instance, a treatment of the combined effluent of a PPM by using a sequential anaerobic and aerobic treatment 
Table 8

Changes in the P\&P mill wastewater parameters after treatment by anaerobic-aerobic combinations.

\begin{tabular}{|c|c|c|c|c|c|c|}
\hline \multirow[t]{3}{*}{ Process } & \multicolumn{5}{|l|}{ Parameters } & \multirow[t]{3}{*}{ References } \\
\hline & \multicolumn{2}{|l|}{ COD } & \multicolumn{3}{|c|}{ Other parameters } & \\
\hline & Initial $(\mathrm{mg} / \mathrm{L})$ & Removal (\%) & Parameter & Initial $(\mathrm{mg} / \mathrm{L})$ & Removal (\%) & \\
\hline $\mathrm{EGSB}+\mathrm{MLE}+\mathrm{UF}$ & $1600-4400$ & 96 & - & - & - & [161] \\
\hline Packed bed AD column + ASP & $\begin{array}{l}2973 \pm 142^{\mathrm{a}} \\
2886 \pm 381^{\mathrm{b}} \\
3901 \pm 1940^{\mathrm{c}} \\
4498 \pm 2020^{\mathrm{d}}\end{array}$ & $55-70$ & & & & [149] \\
\hline \multirow[t]{4}{*}{ Sequential anaerobic-aerobic process } & - & 42 & Colour & - & 70 & [158] \\
\hline & & & Lignin & - & 25 & \\
\hline & & & AOX & - & 15 & \\
\hline & & & Phenol & - & 39 & \\
\hline \multirow[t]{4}{*}{ Sequential anaerobic-aerobic ${ }^{\mathrm{e}}$ process } & - & 88 & Colour & - & 95 & [158] \\
\hline & & & Lignin & - & 86 & \\
\hline & & & AOX & - & 67 & \\
\hline & & & Phenol & - & 63 & \\
\hline \multirow[t]{3}{*}{ UASB + Two-step sequential aerobic reactor ${ }^{f}$} & 5280 & 83.9 & Colour & $5205.5 \mathrm{cu}$ & 87.7 & [159] \\
\hline & & & Lignin & $6380.56 \mathrm{mg} / \mathrm{L}$ & 76.5 & \\
\hline & & & Phenol & $54 \mathrm{mg} / \mathrm{L}$ & 87.2 & \\
\hline
\end{tabular}

\footnotetext{
${ }^{\text {a }}$ Foul condensates.

b Chlorine dioxide bleaching effluents.

c Alkaline extraction reinforced with oxygen and peroxide bleaching effluents.

d Dewatering operation of plant wasted sludge.

e A combination of fungal and bacterial strains.

${ }^{\mathrm{f}}$ Involving Paecilomyces sp. and Pseudomonas syringae pv myricae (CSA105), respectively.
}

in two steps bioreactor was studied by Singh \& Thakur (2006) [158]. They observed 70\%, 42\% and 39\% removals of colour, COD and AOX, respectively, in 15 days. However, using a mixture of fungi and bacteria (Paecilomyces sp. and Microbrevis luteum) for the treatment of anaerobically treated PPM effluents, it was observed 95\%, 67\%, and 88\% reductions in colour, AOX, and COD after 7 and 3 days in the anaerobic and aerobic treatment of the effluents, respectively. Combination of a UASB reactor (step I) and two step sequential aerobic reactor, involving Paecilomyces sp. (step II) and Pseudomonas syringae pv myricae (CSA105) (step III), as aerobic inoculums for the treatment of PPM effluents, has been also investigated by Chuphal, Kumar, \& Thakur (2005) [159]. They indicated that by using such three step fixed film sequential bioreactors, $87.7 \%, 76.5 \%, 83.9 \%$ and $87.2 \%$ removals of colour, lignin, COD, and phenol, respectively, can be achieved. Bal abanič \& Klemenčič (2011) [160], by using full scale aerobic and combined aerobic anaerobic treatment plants, reached removal efficiencies of $87 \%$ and $87 \%$ for dimethyl phthalate, $79 \%$ and $91 \%$ for diethyl phthalate, $73 \%$ and $88 \%$ for dibutyl phthalate, $84 \%$ and $78 \%$ for $\mathrm{di}(2$ ethylhexyl) phthalate, $86 \%$ and $76 \%$ for benzyl butyl phthalate, $74 \%$ and $79 \%$ for bisphenol $\mathrm{A}$ and $71 \%$ and $81 \%$ for nonylphenol from paper mill effluents, respectively. In a study car ried out by Sheldon, Zeelie, \& Edwards (2012) [161], a pilot plant EGSB reactor effectively lowered the COD by 65 to $85 \%$ over a 6 month period. The overall COD removal efficiency after the com bination of an EGSB with a modified Ludzack Ettinger process cou pled with an ultra filter membrane was consistent at $96 \%$. Lin et al. (2014) [148] observed 50 65\% COD removal from four different KP wastewaters (Table 8 ) under AD by using a pilot scale packed bed $\mathrm{AD}$ column at an OLR of $0.24 .8 \mathrm{~kg} \mathrm{COD} / \mathrm{m}^{3} / \mathrm{d}$. The overall COD removal efficiency after combining with completely mixed acti vated sludge process (ASP), as anaerobic aerobic sequential sys tem, was $5570 \%$. Moreover the methane production yield was $0.220 .34 \mathrm{~m}^{3} \mathrm{CH}_{4} / \mathrm{kg}$ COD, with the biogas containing $80 \%$ of methane.

\subsubsection{Future outlook in $A D$ of $P P M W$}

Inherent capabilities of $A D$ reactors can play a significant role in their adoption by P\&P mill to treat various types of PPMW (Table 1). Some of the technologies reviewed in this paper have started to make their way into full scale implementation. The technologies that appear to be at the forefront of AD of PPMW include systems based on suspended growth microorganisms (UASB, SAnMBR and $A B R$ ) and fixed film reactors (AFs, UAPBR). Among the first type of technologies, UASB reactors are currently the dominant full scale facilities adopted by P\&P mills through the world. However, in spite of their high levels of stability (based on the ratio of VFA/Alk indicator) and moderate efficiencies for the removal of COD, BOD and TSS from PPMWs they mainly fail to treat recalci trant compounds such as AOX released to the wastewater from the processes involving the use of chlorinated compounds during the bleaching sequences (Table 1 ). In addition, relatively long HRT requirement of UASBs can also affect their efficiencies when operating in low HRTs which is an urgent need for the P\&P industry to deal with a large amount of the wastewater produced. These can reflect the importance of the adoption of corrective measures such as adoption of appropriate pre treatments methods before AD by UASB reactors. Recent studies have introduced low operating cost reactor configurations such as SGBR, having better efficiencies than UASBs at low HRTs in the lab scales, although not yet widely used to test their performance in full scale treatment of PPMWs. In addition, some measures can also be proposed for the UASB sys tems in order to maintain their removal efficiency while decreasing the HRT. Partial recirculation of the effluent, or cultivation of speci fic microbial strains [123] are among the tested methods in lab scale [124] which need precise cost benefit evaluations in full scale operation to be applicable by the P\&P mills.

Submerged anaerobic membrane reactors (SAnMBR) can be also acceptable choices for the treatment of highly polluted effluents such as kraft evaporator condensate and TMP whitewater, in spite of their main technical difficulties, especially for treatment of PPMW having high TSS and fibrous materials, where membrane fouling has to be overcome. In this sense, low cost methods such as back flush cycles or relaxation are not able to remove the cake sludge (dominate cause of the membrane fouling). Hence, innova tion and application of economic ways to deal with this phe nomenon, like optimization of the most important operating conditions such as transmembrane pressure can help their wider application by P\&P mills. Such improvements are especially of high importance because SAnMBR exhibit a better stability and 
resistance to temperature variation when compared with conven tional high rate anaerobic digesters for the treatment of PPMW and, hence, can be a promising alternative for the conventional high rate anaerobic digesters to be used by P\&P mills. Surface func tionalization is a rapidly developing way to this end. For instance, fouling resistance of PVDF can be enhanced via attachment of appropriate materials to the surface of the membrane. Liang et al. (2013) [162] improved the hydrophobicity of the PVDF through post fabrication tethering of silica nanoparticles (NPs) to the membrane surface in order to form a highly hydrophilic mem brane. Electrical treatment of the membrane surface can also be a good candidate to limit the hydrophobic behavior of the membranes, and so less attachment of the solutes to the mem brane surface. Synthesis and application of new polymers having well defined characteristics is another possibility to optimize the membrane performance. As an example, a polymeric membrane based on sulfonated polycarbonate (SPC) and PVDF developed by Masuelli, Marchese, \& Ochoa (2009) [112] resulted in lower fouling when treating an emulsified oily wastewater, as SPC content increased. Other types of membranes applied so far for the treat ment of a variety of effluents such hollow fiber for tofu processing waste [113] and ceramic tubular for olive mill wastewater [114], are among the applied membranes with external/side stream con figurations which can be also evaluated for the treatment of P\&P mill effluents. Such a configuration can also provide benefits such as easer membrane replacement and providing high flux with more direct control of fouling [163].

ABRs have been rarely applied for the treatment of PPMW, despite having inherent advantages including simplicity, no requirement for gas separation system, low bacterial washout, and the adaptability to the changing operational conditions such as HRT and OLR, which can make them favorable choices, espe cially in the low income countries.

Among the second type of reactors, UAFs and anaerobic fixed film reactors, are good candidates for the efficient removal of AOXs from the P\&P mill effluents, mainly those from ECF bleach ing processes, as observed in lab scale experiments. AFs also have shown the applicability for the removal of sulfate, dominant spe cie in kraft mill effluents (Table 1), as well as other trace metallic materials which can be found in the effluents from RCFs process ing processes. However, in spite of inherent advantages of AFs, such as negligible power requirements, technical difficulties including clogging (as a result of the presence of high amount of suspended solids in P\&P mill effluents), and the cost of the packing materials must be overcome to facilitate their transfer from lab scale to full scale applications. Some innovations such as periodic irradiation of ultrasound waves and the fabrication of low cost and high efficient filter media (i.e. biotrickling filters [164]), can be proposed as the main areas for further studies to overcome such deficiencies.

Thermophilic digesters can also give a superior stability when compared to mesophilic digesters for a wide range of highly pol luted PPMWs like those from chemical pulping (especially ECF). However, utilization of high temperature conditions may alter the energy saving strategies of P\&P mills. In this regard, it would be also of high importance for future studies to evaluate the perfor mance of low temperature AD by adopting some strategies like co digestion with other substrates for the treatment of PPMW.

The pre treatment methods have been applied so far for the remediation of wastes containing AOXs (Table 2), are also mainly unable to degrade and remove these compounds from the wastes content. In this sense, state of the art technologies, especially appli cation of engineered nanomaterials (ENMs), can assist the degrada tion of AOXs from the PPMW, and enhance the biodegradability of the streams, providing a potentially cost effective and efficient solution. It is also of high importance to develop novel methods for the green fabrication of ENMs having enhanced and modified properties for such application as well as the facile and applicable methods for the collection of the used ENMs.

Some other features of the PPMW, such as the alkaline nature of the wastes from some P\&P production processes (such as Kraft pulping) or toxic effects of the acidic effluents, like those from ECF (Table 1) may considerably restrict the efficiency of any AD technology. Innovation on multi stage AD reactors, able to separate the hydrolysis/acidification from acetogenesis/methanogenesis phases (Fig. 4) with acceptable performance criteria (i.e. HRT, OLR, removal efficiency, etc.), and adoption of strategies such as co digestion with appropriate substrates, in order to increase the buffering capacity and neutralization of the P\&P effluents, are the subject for further studies in this field. Sequential bioreactors including anaerobic and aerobic digestion systems (especially a combination of fungal and bacterial strains) has been also of high effectiveness for COD removal and to some extent removal of AOXs, lignin and colour from PPMWs. This combined strategy could also be used as a solution for the problems of the conven tional anaerobic digesters (such as UASB) when the HRT decreases; because the experimental analysis have shown relatively high per formance for this combined systems at relatively low HRTs. In addition, it should also be mentioned that the performance of the $\mathrm{AD}$ systems for the treatment of PPMW when exposed to shocks in the operating conditions, and their recovery potential has not been well documented so far.

Anaerobic digestion of PPMW rate can be limited by the quan tity of the most limiting elements (i.e. nitrogen phosphorous), according to the Liebig's law [165]. An applicable method for the nutrient deficiency compensation seems to be the co digestion of PPMW with appropriate substrates. However, real applications of such strategies are highly scarce, whereas it can be a very interest ing choice in order to do the integration of different treatment plants. However, In some cases, such as the effluents from Eucalyp tus sp. P\&P making processes (Fig. 1), there may be relatively high amounts of phosphorous which may need novel techniques to pre vent discharging the phosphorus based compounds, in higher amounts than their limits according to the environmental protec tion standards. On the other hand, the presence of some toxic com pounds can limit the AD of P\&P mill wastes. With respect to sulfide, some measures such as pre oxidization [148] can be a possible solution. However, in the presence of sulfate reducing bacteria, $\mathrm{H}_{2} \mathrm{~S}$ will be released, which is the most toxic form of the sulfide species for the microbial communities. Such species can also pro mote the corrosion of the concrete in full scale reactors, caused by the hydrogen sulfide released in the media, or interrupting the methane yield through for instance the anaerobic oxidation of the methane through the following equation [166]:

$$
\mathrm{CH}_{4}+\mathrm{SO}_{4}^{2} \rightarrow \mathrm{HCO}_{3}+\mathrm{HS}+\mathrm{H}_{2} \mathrm{O}
$$

However, studies on the conversion or removal of sulfide from the P\&P mill effluents are scarce. Multi stage reactors may be a good option for this purpose. Moreover, there is a lack for studies on the presence of sulfate reducing bacteria in the $\mathrm{AD}$ microbial population and their effects on the inhibition of the methane yield. For other inhibitory elements, such as tannins, which are consid ered as the main portion of the P\&P mill effluents (Table 1), AOXs, resin acids, etc., in spite of their evident toxic effects on the micro bial communities, there is still a need for further comparative stud ies to quantify their exact effects on the methane production, as well as the economic and effective innovative methods for the degradation (or removal) of these compounds from the streams. One effective way to deal with the inhibitors and also with non biodegradable compounds is applying a physico chemical and bio logical pre treatment. However, there is a lack of knowledge on the 
direct effects of such methods on both the methane yield and AD removal efficiency. Coagulation, flocculation, precipitation, oxidation, adsorption, and filtration are the main physico chemical techniques that have been applied so far for the treat ment of P\&P wastewater (Table 7). However, several technical and economic considerations have limited their wider application at full scale. Membrane based technologies are mainly struggling with technical deficiencies (such membrane fouling) and conven tional oxidation processes are of high expense to be adopted economically by the P\&P mills. Moreover, applying methods such as sedimentation can remove high weight fibrous materials from the content of P\&P wastewater which may affect the yield of the following $\mathrm{AD}$. In spite of innovation of some economic and theoretically applicable methods such as advanced oxidative processes (AOPs) by using nano catalytic materials, they have not been used for the pre treatment of PPMW. Ultrasonic irradiation $(20 \mathrm{kHz} 10 \mathrm{MHz})$, which has been used previously as a pre treatment for some types of effluents, such as municipal wastewaters [167] can also be applied before AD of PPMW. It may increase the homogeneity of the effluents and transform some hardly biodegradable fractions, as a result of direct high intensity energy of ultrasonic irradiation or, indirectly, under the effect of high speed jets or shock waves $(400 \mathrm{~km} / \mathrm{h}$ ) produced by collapsing the bubbles which form and grow under ultrasonic irradiation, and experience instantaneous implosive collapse [168].

Although pre treatment methods have been applied so far for the remediation of wastes containing AOXs (Table 2), they are also mainly unable to degrade and remove these compounds from the wastes content. In this sense, an evolution had occurred in the state of the art technologies, especially the application of engineered nanomaterials (ENMs), which can assist the degradation of AOXs from the PPMW, and enhance the biodegradability of the streams, providing a potentially cost effective and efficient solution. In this area of study, it is also of high importance to develop novel methods for the green fabrication of ENMs having enhanced and modified properties for such application as well as to develop facile and applicable methods for the collection of the used ENMs.

\subsection{AD of PPM sludge}

Pre treatment methods and co digestion strategies are the main approaches used so far to enhance the AD of PPMS.

\subsubsection{Pre treatment strategies}

It seems that pre treatment methods are very effective in order to reduce the residence time and to enhance the performance of the $\mathrm{AD}$ systems, and, hence, to reduce the treatment costs. Yunqin, Dehan, Shaoquan, \& Chunmin (2009) [169] investigated the effects of the pre treatment of the PPMS with $\mathrm{NaOH}$, prior to AD. They observed that by performing this pre treatment, the SCOD of the sludge increased, and, as a consequence, a $5488 \%$ improvement in the methane production was achieved. Park et al. (2012) [52] achieved no significant methane production improvement when the thickened PPMS (65 g/ $/ \mathrm{kg}$ TS) was subject to a pre treatment with $\mathrm{NaOH}(0.261 \mathrm{~g} / \mathrm{g} \mathrm{TS})$, or to an ultrasonic pre treatment $(16.8 \mathrm{MJ} / \mathrm{kg}$ TS) before AD. However, the initial rate of methane production increased and, as a result of the pre treatment, $80 \%$ of total methane yield was reached 5.5 6.5 days faster. Moreover, Bayr, Kaparaju, \& Rintala (2013) [170] indicated that ultrasound method could not improve the methane yield, when used as pre treatment for AD of secondary PPMS. They investigated 12 dif ferent pre treatment methods in this regard and concluded that hydrothermal pretreatment $\left(150^{\circ} \mathrm{C}, 10 \mathrm{~min}\right)$, alone or in combina tion with enzymatic and/or ultrasound pretreatment can result in the highest methane yield. Wood, Tran, \& Master (2009) [171] achieved similar results with respect to the efficiency of the thermal pre treatment of the kraft and sulfide sludge samples, when compared to other studied pre treatments, including ther mochemical (caustic) and sonication. Saha, Eskicioglu, \& Marin (2011) [172] studied the effects of the microwave $(2450 \mathrm{MHz}$, $1250 \mathrm{~W})$, ultrasonic $(20 \mathrm{kHz}, 400 \mathrm{~W})$ and chemo mechanical (MicroSludge $^{\circledR}$ with $900 \mathrm{mg} / \mathrm{L} \mathrm{NaOH}$ followed by $83,000 \mathrm{kPa}$ ) pre treatments on the methane production from pulp mill wastewater treatment sludge. They observed that the microwave pretreatment was the most effective method, resulting in a $90 \%$ increase in the specific methane yield, when compared to controls after 21 days under mesophilic digestion of secondary sludge. Moreover, although sonication showed a better effect on the COD solubiliza tion, it resulted in soluble non biodegradable compounds. Table 9 summarizes the results of the recent studies on the PPMS pre treatments.

Moreover, there is a potential improvement in the treatment process through the application of advanced materials and tech nologies such as ENMs which experienced a rapid transfer from laboratory to field scale applications in various scientific fields

Table 9

The AD performance with pre-treatment methods for treatment of PPMS.

\begin{tabular}{|c|c|c|c|c|c|c|}
\hline \multirow[t]{2}{*}{ Sludge } & \multirow[t]{2}{*}{ Method } & \multirow{2}{*}{$\begin{array}{l}\text { SCOD (Before } \\
\text { pre-treatment) } \\
(\mathrm{mg} / \mathrm{L})\end{array}$} & \multicolumn{2}{|c|}{$\underline{\mathrm{SCOD}(\mathrm{AD})}$} & \multirow{2}{*}{$\begin{array}{l}\text { Methane } \\
\text { production } \\
\text { improvement (\%) }\end{array}$} & \multirow[t]{2}{*}{ References } \\
\hline & & & $\begin{array}{l}\text { Initial } \\
(\mathrm{mg} / \mathrm{L})\end{array}$ & $\begin{array}{l}\text { Removal } \\
(\%)\end{array}$ & & \\
\hline $\begin{array}{l}\text { Mixture of primary and } \\
\text { secondary sludge }\end{array}$ & Alkali pre-treatment ( $\left.8 \mathrm{~g} \mathrm{NaOH} / 100 \mathrm{~g} \mathrm{TS}_{\text {sludge }}\right)$ & - & 14778.6 & 93 & 83 & [169] \\
\hline Secondary sludge (TMP) & Alkali + Ultrasound pre-treatment & - & $\sim 13,000$ & - & $3-7$ & {$[52]$} \\
\hline \multirow[t]{4}{*}{ Secondary sludge $(\mathrm{KP})^{\mathrm{a}}$} & Hydrothermal pretreatment & 800 & 9000 & - & 54 & [170] \\
\hline & Hydrothermal + Enzymatic pretreatment & 800 & 9000 & - & 41 & \\
\hline & Ultrasound + Hydrothermal pretreatment & 800 & 9000 & - & 52 & \\
\hline & Ultrasound + Hydrothermal + Enzymatic pretreatment & 800 & 10,000 & - & 57 & \\
\hline \multirow[t]{2}{*}{ Secondary sludge (pulp mill ${ }^{\mathrm{b}}$ ) } & Thermal pretreatment & $1.4 \pm 0.03$ & $8.5 \pm 1.0$ & - & 50 & {$[171]$} \\
\hline & Thermochemical pretreatment & $1.4 \pm 0.03$ & $9.7 \pm 1.0$ & - & 18 & \\
\hline \multirow{2}{*}{$\begin{array}{l}\text { Mixture of primary and } \\
\text { secondary sludge }^{c}\end{array}$} & Microwave pre-treatment $\left(175^{\circ} \mathrm{C}\right)$ & 1926 & $-{ }^{\mathrm{d}}$ & $-{ }^{\mathrm{e}}$ & $\sim 80^{\mathrm{f}}$ & {$[172]$} \\
\hline & Ultrasonic $\left(90^{\circ} \mathrm{C}\right)$ & 1926 & $-g$ & $-{ }^{\mathrm{h}}$ & $\sim 90^{\mathrm{c}}$ & \\
\hline
\end{tabular}

a Integrated bleached (chlorine dioxide, oxygen) KP (softwood and birch) and paper mill (producing coated magazine paper).

b Ammonium sulfite mill, and a kraft mill.

c Pulp mill WAS and WAS + PS (40:60\% v/v) mixed sludge.

d SCOD/total chemical oxygen demand (TCOD): $41 \pm 2.1 \%$.

e TCOD removal: $30 \%$.

${ }^{f}$ Based on the specific methane yield $\left(\mathrm{mL} / \mathrm{mg}\right.$ TCOD $\left.{ }_{\text {added }}\right)$ after 21 days.

g SCOD/TCOD: $42 \pm 2.1 \%$

h TCOD removal: $30 \%$. 
Table 10

Characteristics of the primary, secondary and mixed PPMS.

\begin{tabular}{|c|c|c|c|c|c|c|}
\hline \multirow[t]{2}{*}{ Sludge type } & \multicolumn{5}{|c|}{ Characteristics } & \multirow[t]{2}{*}{ References } \\
\hline & $\mathrm{COD}(\mathrm{mg} / \mathrm{L})$ & TS (\%) & VS (\% of TS) & $\mathrm{pH}$ & $\mathrm{C} / \mathrm{N}$ ratio & \\
\hline Primary sludge $^{a}$ & - & 3.4 & 86 & 6.2 & - & [53] \\
\hline Secondary sludge ${ }^{a}$ & & 4.0 & 82 & 7.6 & - & [53] \\
\hline Secondary sludge $^{\mathrm{b}}$ & 29,800 & 24.2 & 77.0 & 7.3 & $10.5: 1$ & {$[52]$} \\
\hline Secondary sludge ${ }^{c}$ & - & 4.7 & 83 & - & - & {$[170]$} \\
\hline Secondary sludge $^{\mathrm{d}}$ & 11,700 & $11.1(\mathrm{mg} / \mathrm{L})$ & - & - & & {$[171]$} \\
\hline Secondary sludge $\mathrm{e}^{\mathrm{e}}$ & 27,000 & $24.4(\mathrm{mg} / \mathrm{L})$ & - & - & & [171] \\
\hline Secondary sludge & 39,579 & 2.50 & 80 & 6.5 & & {$[172]$} \\
\hline Primary + secondary sludge & 34,229 & 2.21 & 83 & 6.2 & & {$[172]$} \\
\hline Primary + secondary sludge & - & 31.45 & 62.3 & 7.82 & 30.05 & [169] \\
\hline
\end{tabular}

a Integrated bleached kraft pulp (softwood and birch) and paper mill.

b Bleached CTMP and TMP.

c Integrated bleached kraft P\&P mill.

d Sulfite mill.

e Kraft mill.

[173]. Such novel materials are used to remove trace elements such as Ni, Cd, and Pb [174] which may be found in PPMS [175], mainly through sorbtive techniques [176]. Moreover, they seem to be able to break down non biodegradable compounds like cellu losic biomass (i.e., cellulose, hemicellulose, and lignin [177] which resists the hydrolytic enzymes [178]. This may lead to enhance the biodegradability index (BI), and an improvement in the yield of the biological treatment.

\subsubsection{Co digestion}

Nutrient deficiency, and also lignin and sulphur containing sub stances are considered the main drawbacks which may cause an incomplete anaerobic treatment of P\&P mill wastes. Hagelqvist (2013) [179] indicated the feasibility of the secondary sludge from CTMP, from KP process, and from food packaging board to be co digested with municipal sewage sludge, without significant reduc tion in methane production, but a small increase in the solid resi due's cadmium content. Bayr \& Rintala (2012) [53] achieved methane yields of $150170 \mathrm{~m}^{3} / \mathrm{tVS}_{\text {fed }}$ by anaerobic co digestion of primary and secondary sludge with OLR of $1 \mathrm{~kg} \mathrm{VS} / \mathrm{m}^{3} \mathrm{~d}$ and HRT of $2531 \mathrm{~d}$. In order to do adjustments of the $\mathrm{C} / \mathrm{N}$ ratio, Lin et al. (2011) [147] investigated co digestion of the PPMS with monosodium glutamate waste liquor by using a bench scale anaerobic digester under mesophilic conditions. They observed no inhibitions due to VFAs and ammonia on the anaerobic co digestion process, with an accumulative methane yield attained of $200 \mathrm{~mL} / \mathrm{g} \mathrm{VS}_{\text {added }}$ and a peak value of daily methane production of $0.5 \mathrm{~m}^{3}$. Lin et al. (2013) [14] designed a mesophilic anaerobic bio hydrogen production and a mesophilic anaerobic process for methane production, for co digestion of PPMS and food wastes. They achieved $64.48 \mathrm{~mL} / \mathrm{g} \mathrm{VS}_{\text {fed }}$ and $432.3 \mathrm{~mL} / \mathrm{g} \mathrm{VS}$ fed yields for hydrogen and methane production, respectively, at an optimal ratio of PPS and food wastes (1:1 VS), as the feedstock. In this situation, a maximum of $87 \%$ removal efficiency on the SCOD was achieved.

\subsubsection{PPMS: criticisms and future outlook}

$\mathrm{AD}$ has been traditionally utilized for decades, as an attractive way to stabilize primary, secondary and mixed sludge having high levels of biodegradable materials, and to produce biogas, as a source of renewable energy form these types of wastes. However, compared to PPMW, there are a limited number of reports about AD of PPMS, especially for the (semi) continuous AD of P\&P pri mary sludge (Table 10). This may be to the fact that the primary sludge from P\&P mill production processes are rich in fibrous materials and, hence, is recovered instead of being anaerobically digested. However, the PPMS is generally low in organic matters, especially biodegradable compounds; they have typically low methane potentials. It is mainly attributed to the fact that they have been already degraded by physico chemical or biological treatments. In this regard, application of pre treatment technolo gies, especially chemical (e.g., alkali) ones as cost effective ways, can promote the biogas production, through the disintegration of sludge cells and enhancing the availability of the biodegradable compounds for $\mathrm{AD}$ microorganisms. However, it seems that in order to achieve the maximum energy production, in line with environmental considerations, the main priority must be to develop and promote the efficient methods to AD treatment of PPMW to maximize the biogas production resulting in a low sludge production which can meet discharge standards to be used, for instances, in land applications safely.

In spite of the recent advances in the anaerobic digestion of the P\&P mill wastes, digested streams may still contain compounds like lignin, tannin, etc. (Table 1); contributing to color of the leachate/ effluents, as well as microorganisms, suspended solids and other pollutants including non biodegradable compounds and relatively low quantities of remained biodegradable organics $[82,180]$. Hence, tertiary treatments such as membrane separation [82], adsorption [181], ion exchanging [182], and chemical oxida tion process $[180,183,184]$ may be vital if the sludge (or wastewa ter) is desired to be recycled in the manufacturing processes. Composting for the $\mathrm{AD}$ residual to form a soil conditioner can also be performed on the AD residuals [185].

\section{Conclusion}

High COD concentrations contributing to the $5560 \%$ of the original weight of the wood [11] and additives used (Table 1) can strongly support the idea of the AD of P\&P mill wastes in order to reduction of pollution load, and production of biogas, as a renewable source of energy. However, several factors are involved in the AD of P\&P mill wastes (graphical abstract) which should be taken into consideration carefully to achieve the desirable methane production and treatment efficiency for this process. Anaerobic digesters having internal settlers such as UASB reactors are the dominant reactor systems for the treatment of PPMWs. Such reac tors have shown a moderate to high performance to reduce the COD and various removal efficiencies for other parameters includ ing BOD, TSS, AOX, etc., depending on the reactor design, operating conditions and the properties of the streams. While the relatively long HRT has been the main shortfall in the performance of UASB systems, the maintenance and the additional costs are considered the most significant obstacles for AnMBRs. In addition, the cost of the packing materials has been considered the cause of the 
limited applications of AFs to deal with PPMWs. The microbial activity and its impact on the overall performance of the $A D$ reac tors for methane production and COD (and other pollutants) removal can be highly influenced by the reactor operating condi tions including HRT, OLR, operating temperature, and $\mathrm{pH}$, as well as the presence of inhibitory elements such as sulfide compounds. Nevertheless, the performance of the AD systems for the treatment of P\&P mill wastes when exposed to shocks in the operating condi tions, and their recovery potential has not been well documented so far. In addition, the development of reliable sensing systems for a continuous measurement and adjustment of the operating conditions would be an essential need to promote the methane yield from $A D$, especially when applied to P\&P mill wastes as com plex high strength substrates. In addition, there is a lack in the investigation of the direct effects of physico chemical and biologi cal pre treatments on both the methane yield and removal effi ciency of $A D$ reactors. The research on the PPMS has clearly indicated that chemical (e.g., alkali) pre treatments are acceptable and cost effective ways to enhance the AD of both primary and secondary sludge, when compared to other studied methods. Com bination of aerobic and anaerobic technologies have also been identified as a promising way to enhance either the overall perfor mance of the treatment process for P\&P mill wastes, or to satisfy the stringent environmental regulations. However, most of the developments in the AD of P\&P mill wastes which have been reviewed in this paper have not been implemented in full scale applications. In this regard, further work is required to evaluate and enhance the performance of these promising lab scale tech nologies for large scale operation in P\&P mills.

\section{Acknowledgements}

Thanks are due, for the financial support to CESAM (UID/ $\mathrm{AMB} / 50017)$, to CICECO Aveiro Institute of Materials, POCI 01 0145 FEDER 007679 (FCT Ref. UID/CTM/50011/2013), to FCT/ MEC through national funds, and the co funding by the FEDER, within the PT2020 Partnership Agreement and Compete 2020. Thanks are also due to FCT for the doctoral scholarship $\mathrm{N}^{\circ} \mathrm{SFRH} /$ BD/103695/2014.

\section{References}

[1] FAO, ForesSTAT database 2012, 2012. [Online]. Available: http://faostat.fao. org/site/626/default.aspx\#ancor.

[2] M. Kamali, Z. Khodaparast, Review on recent developments on pulp and paper mill wastewater treatment, Ecotoxicol. Environ. Saf. 114 (2015) 326-342.

[3] X. Ji, J. Lundgren, C. Wang, J. Dahl, C.-E. Grip, Simulation and energy optimization of a pulp and paper mill - Evaporation plant and digester, Appl. Energy 97 (2012) 30-37.

[4] European Commission, Integrated Pollution Prevention and Control (IPPC)Reference document on best available techniques in the pulp and paper industry, 2001.

[5] K. Ericsson, L.J. Nilsson, M. Nilsson, New energy strategies in the Swedish pulp and paper industry - The role of national and EU climate and energy policies, Energy Policy 39 (2011) 1439-1449.

[6] D.K. Tiku, A. Kumar, S. Sawhney, V.P. Singh, R. Kumar, Effectiveness of treatment technologies for wastewater pollution generated by Indian pulp mills, Environ. Monit. Assess. 132 (2007) 453-466.

[7] A. Waye, M. Annal, A. Tang, G. Picard, F. Harnois, J.A. Guerrero-analco, A. Saleem, L.M. Hewitt, C.B. Milestone, D.L. Maclatchy, V.L. Trudeau, J.T. Arnason, Canadian boreal pulp and paper feedstocks contain neuroactive substances that interact in vitro with GABA and dopaminergic systems in the brain, Sci. Total Environ. 468-469 (2014) 315-325.

[8] M.M. Maghanaki, B. Ghobadian, G. Najafi, R.J. Galogah, Potential of biogas production in Iran, Renewable Sustainable Energy Rev. 28 (2013) 702-714.

[9] J.A. Siles, J. Brekelmans, M.A. Martín, A.F. Chica, A. Martín, Impact of ammonia and sulphate concentration on thermophilic anaerobic digestion, Bioresour. Technol. 101 (2010) 9040-9048.

[10] S. Jewitt, Poo gurus? Researching the threats and opportunities presented by human waste, Appl. Geogr. 31 (2011) 761-769.

[11] Y. Chen, J.J. Cheng, K.S. Creamer, Inhibition of anaerobic digestion process: a review, Bioresour. Technol. 99 (2008) 4044-4064.
[12] M. Henze, P. Harremoës, Anaerobic treatment of wastewater in fixed film reactors - A literature review, Water Sci. Technol. 15 (1983) 1-101.

[13] S. Chong, T.K. Sen, A. Kayaalp, H.M. Ang, The performance enhancements of upflow anaerobic sludge blanket (UASB) reactors for domestic sludge treatment-a state-of-the-art review, Water Res. 46 (2012) 3434-3470.

[14] H. Lin, W. Peng, M. Zhang, J. Chen, H. Hong, Y. Zhang, A review on anaerobic membrane bioreactors: Applications, membrane fouling and future perspectives, Desalination 314 (2013) 169-188.

[15] T. Amani, M. Nosrati, T.R. Sreekrishnan, Anaerobic digestion from the viewpoint of microbiological, chemical, and operational aspects - A review, Environ. Rev. 18 (2010) 255-278.

[16] J. Mata-Alvarez, J. Dosta, M.S. Romero-Güiza, X. Fonoll, M. Peces, S. Astals, A critical review on anaerobic co-digestion achievements between 2010 and 2013, Renewable Sustainable Energy Rev. 36 (2014) 412-427.

[17] Y.J. Chan, M.F. Chong, C.L. Law, D.G. Hassell, A review on anaerobic-aerobic treatment of industrial and municipal wastewater, Chem. Eng. J. 155 (2009) $1-18$.

[18] J.A. Rintala, J.A. Puhakka, Anaerobic treatment in pulp and paper mill waste management: A review, Bioresour. Technol. 47 (1994) 1-18.

[19] A. Elliott, T. Mahmood, Pretreatment technologies for advancing anaerobic digestion of pulp and paper biotreatment residues, Water Res. 41 (2007) 4273-4286.

[20] Fao, pulp and paper capacities capacités de la pâte et du papier capacidades de pasta y papel-survey enquête estudio 2013-2018, 2014.

[21] D.S. Fraser, K. O'Halloran, M.R. Van den Heuvel, Toxicity of pulp and paper solid organic waste constituents to soil organisms, Chemosphere 74 (2009) 660-668.

[22] M.J. Martınez-Inigo, A. Gutierrez, J.C. del Rı, M.J. Martınez, A.T. Martınez, Time course of fungal removal of lipophilic extractives from Eucalyptus globulus wood, J. Biotechnol. 84 (2000) 119-126.

[23] Central Pulp and Paper Research Institute (CPPRI), "Statistics of the Indian Paper Industry. In: Directory of Indian Paper Industry, vol. II”, Saharanpur, India, 2005.

[24] A. Oudia, J. Queiroz, R. Simões, Potential and limitation of Trametes versicolor laccase on biodegradation of Eucalyptus globulus and Pinus pinaster kraft pulp, Enzyme Microb. Technol. 43 (2008) 144-148.

[25] Y. Chen, J. Wan, M. Huang, Y. Ma, Y. Wang, H. Lv, J. Yang, Influence of drying temperature and duration on fiber properties of unbleached wheat straw pulp, Carbohydr. Polym. 85 (2011) 759-764.

[26] Secretariat of the Convention on Biological Diversity, Recognition and support of iccas in Russia territories and areas conserved by indigenous peoples, Global overview and national case studies, CBD Technical Series No. 64, 2012.

[27] S. González-García, S. Berg, M.T. Moreira, G. Feijoo, Evaluation of forest operations in Spanish eucalypt plantations under a life cycle assessment perspective, Scand. J. For. Res. 24 (2009) 160-172.

[28] P. Bajpai, Pulp and Paper Industry, Elsevier, 2015.

[29] H. Toivanen, Innovation in the U.S. pulp and paper industry: lessons for Brazil, O Papel 74 (2013) 55-58.

[30] V. Honnold, Developments in the sourcing of raw materials for the production of paper, J. Int. Commer. Econ. (2009) 1-26.

[31] T. Bond, M.R. Templeton, History and future of domestic biogas plants in the developing world, Energy Sustainable Dev. 15 (2011) 347-354.

[32] T. Abbasi, S.M. Tauseef, S.A. Abbasi, Anaerobic digestion for global warming control and energy generation-An overview, Renewable Sustainable Energy Rev. 16 (2012) 3228-3242.

[33] N. Curry, P. Pillay, Biogas prediction and design of a food waste to energy system for the urban environment, Renewable Energy 41 (2012) 200-209.

[34] IEE, Sustainable energy projects for local economic development, 2007.

[35] U. Marchaim, Biogas Processes for Sustainable Development, Food and Agriculture Organization of the United Nations, Rome, 2004.

[36] H. Mae-Wan, Biogas bonanza for third world development, Institute of Science in Society, 2008 [Online]. Available: http://www.i-sis.org.uk/BiogasBonanza. php.

[37] G. Cillie, M. Henzen, G. Stander, R. Baillie, Anaerobic digestion-IV. The application of the process in waste purification, Water Res. 3 (9) (1969) 623643.

[38] R. Bointner, Innovation in the energy sector: Lessons learnt from R\&D expenditures and patents in selected IEA countries, Energy Policy 73 (2014) $733-747$.

[39] K. Braber, B.V. Novem, Anaerobic digestion of municipal solid waste: a modern waste disposal option on the verge of breakthrough, Bioresour. Technol. 9 (1995) 365-376.

[40] L. Habets, W. Driessen, Anaerobic treatment of pulp and paper mill effluents Status quo and new developments, Water Sci. Technol. 55 (6) (2007) $223-$ 230.

[41] K.C. Surendra, D. Takara, J. Jasinski, S. Kumar Khanal, "Household anaerobic digester for bioenergy production in developing countries: opportunities and challenges", Environ. Technol. 34 (2013) 1671-1689.

[42] P. Vandevivere, New and broader applications of anaerobic digestion, Crit. Rev. Environ. Sci. Technol. 29 (1999) 151-173.

[43] H. Holik (Ed.), Handbook of Paper and Board, Wiley-VCH, Weinheim, 2006.

[44] J. Hong, X. Li, Environmental assessment of recycled printing and writing paper: a case study in China, Waste Manage. 32 (2) (2012) 264-270.

[45] P.S. Wiegand, C.A. Flinders, G.G. Ice, D.J.H. Sleep, B.J. Malmberg, and I. Lama, Water profiles of the forest products industry and their utility in sustainability assessment, Tappi J., 19-27, 2011. 
[46] J.-P. Wang, Y. Chen, Y. Wang, S.-J. Yuan, H. Yu, Optimization of the coagulation-flocculation process for pulp mill wastewater treatment using a combination of uniform design and response surface methodology, Water Res. 45 (2011) 5633-5640.

[47] M. Sainlez, G. Heyen, Comparison of supervised learning techniques for atmospheric pollutant monitoring in a Kraft pulp mill, J. Comput. Appl. Math. 246 (2013) 329-334.

[48] P.K. Tewari, V.S. Batra, M. Balakrishnan, Efficient water use in industries: Cases from the Indian agro-based pulp and paper mills, J. Environ. Manage. 90 (2009) 265-273.

[49] C. Rıo, A. Gutierrez, F.J. Gonzalez-vila, F. Martın, Characterization of organic deposits produced in the kraft pulping of Eucalyptus globulus wood, J. Chromatogr. A 823 (1998) 457-465.

[50] O. Ashrafi, L. Yerushalmi, F. Haghighat, Wastewater treatment in the pulpand-paper industry: A review of treatment processes and the associated greenhouse gas emission, J. Environ. Manage. 158 (2015) 146-157.

[51] D. Pokhrel, T. Viraraghavan, Treatment of pulp and paper mill wastewater - A review, Sci. Total Environ. 333 (2004) 37-58.

[52] N.D. Park, S.S. Helle, R.W. Thring, Combined alkaline and ultrasound pretreatment of thickened pulp mill waste activated sludge for improved anaerobic digestion, Biomass Bioenergy 46 (2012) 750-756.

[53] S. Bayr, J. Rintala, Thermophilic anaerobic digestion of pulp and paper mill primary sludge and co-digestion of primary and secondary sludge, Water Res. 46 (2012) 4713-4720.

[54] E. Avsar, G.N. Demirer, Cleaner production opportunity assessment study in SEKA Balikesir pulp and paper mill, J. Cleaner Prod. 16 (2008) 422-431.

[55] M. Ali, T.R. Sreekrishnan, Aquatic toxicity from pulp and paper mill effluents: a review, Adv. Environ. Res. 5 (2001) 175-196.

[56] M. Vepsäläinen, H. Kivisaari, M. Pulliainen, A. Oikari, M. Sillanpää, Removal of toxic pollutants from pulp mill effluents by electrocoagulation, Sep. Purif Technol. 81 (2011) 141-150.

[57] E. Ekstrand, M. Larsson, X. Truong, L. Cardell, Y. Borgström, A. Björn, J. Ejlertsson, B.H. Svensson, F. Nilsson, A. Karlsson, Methane potentials of the Swedish pulp and paper industry - A screening of wastewater effluents, Appl. Energy 112 (2013) 507-517.

[58] B. Bilitewski, R.M. Darbra, D. Barcelo (Eds.), Global Risk-Based Management of Chemical Additives I: Production, Usage and Environmental Occurrence, Springer, London, New York, 2012.

[59] M. Betancur, P.R. Bonelli, J.A. Velásquez, A.L. Cukierman, Potentiality of lignin from the Kraft pulping process for removal of trace nickel from wastewater: Effect of demineralisation, Bioresour. Technol. 100 (2009) 1130-1137.

[60] T.S. Huuha, T.A. Kurniawan, M.E.T.T. Sillanpää, Removal of silicon from pulping whitewater using integrated treatment of chemical precipitation and evaporation, Chem. Eng. J. 158 (2010) 584-592.

[61] X. Qu, W.J. Gao, M.N. Han, A. Chen, B.Q. Liao, Integrated thermophilic submerged aerobic membrane bioreactor and electrochemical oxidation for pulp and paper effluent treatment - Towards system closure, Bioresour. Technol. 116 (2012) 1-8.

[62] B. Wang, L. Gu, H. Ma, Electrochemical oxidation of pulp and paper making wastewater assisted by transition metal modified kaolin, J. Hazard. Mater. 143 (2007) 198-205.

[63] L. Lei, Y. Li, and X. Zhang, Color removal and biodegradability enhancement of chemical pretreatment effluent of eucalyptus chemithermomechanical pulp (CTMP) by zero-valent iron, in: 3rd International Conference on Bioinformatics and Biomedical Engineering, ICBBE 2009, 2009, 4925-4929.

[64] A. Requejo, A. Rodríguez, J.L. Colodette, J.L. Gomide, L. Jiménez, TCF bleaching sequence in kraft pulping of olive tree pruning residues, Bioresour. Technol. 117 (2012) 117-123.

[65] B. Karrasch, O. Parra, H. Cid, M. Mehrens, P. Pacheco, R. Urrutia, C. Valdovinos, C. Zaror, Effects of pulp and paper mill effluents on the microplankton and microbial self-purification capabilities of the Biobıo River, Chile, Sci. Total Environ. 359 (2006) 194-208.

[66] J. Koistinen, J. Paasivirta, T. Nevalainen, M. Lahtiperä, Chlorinated fluorenes and alkylfluorenes in bleached kraft pulp and pulp mill discharges, Chemosphere 28 (1994) 2139-2150.

[67] M. Uğurlu, M.H. Karaoğlu, Removal of AOX, total nitrogen and chlorinated lignin from bleached Kraft mill effluents by UV oxidation in the presence of hydrogen peroxide utilizing TiO2 as photocatalyst, Environ. Sci. Pollut. Res. 16 (2009) 265-273.

[68] S.K. Kansal, M. Singh, D. Sud, Effluent quality at kraft/soda agro-based paper mills and its treatment using a heterogeneous photocatalytic system, Desalination 228 (2008) 183-190.

[69] M. Ali, T.R. Sreekrishnan, Anaerobic treatment of agricultural residue based pulp and paper mill effluents for AOX and COD reduction, Process Biochem. 36 (2000) 25-29.

[70] M.S. Nasser, F.A. Twaiq, S.A. Onaizi, Effect of polyelectrolytes on the degree of flocculation of papermaking suspensions, Sep. Purif. Technol. 103 (2013) 43-52.

[71] A.A. Guedez, W. Püttmann, Printing ink and paper recycling sources of TMDD in wastewater and rivers, Sci. Total Environ. 468-469 (2014) 671-676.

[72] S.P. Raut, R. Sedmake, S. Dhunde, R.V. Ralegaonkar, S.A. Mandavgane, Reuse of recycle paper mill waste in energy absorbing light weight bricks, Constr. Build. Mater. 27 (2012) 247-251.

[73] R. Miranda, A. Blanco, C. Negro, Accumulation of dissolved and colloidal material in papermaking-Application to simulation, Chem. Eng. J. 148 (2009) 385-393.
[74] S. Zhenying, D. Shijin, C. Xuejun, G. Yan, L. Junfeng, W. Hongyan, S.X. Zhang, Combined de-inking technology applied on laser printed paper, Chem. Eng. Process. Process Intensif. 48 (2009) 587-591.

[75] H.M. Zwain, S. Roshayu, N. Qamaruz, H. Abdul, I. Dahlan, S.R. Hassan, N.Q. Zaman, H.A. Aziz, I. Dahlan, The start-up performance of modified anaerobic baffled reactor (MABR) for the treatment of recycled paper mill wastewater, J. Environ. Chem. Eng. (2013) 61-64.

[76] S.R. Hassan, H.M. Zwain, N.Q. Zaman, I. Dahlan, Recycled paper mill effluent treatment in a modified anaerobic baffled reactor: start-up and steady-state performance, Environ. Technol. 35 (3) (2014) 294-299.

[77] X. Zhang, S. Renaud, M. Paice, Cellulase deinking of fresh and aged recycled newsprint/magazines (ONP/OMG), Enzyme Microb. Technol. 43 (2008) 103108.

[78] M.C. Monte, E. Fuente, A. Blanco, C. Negro, Waste management from pulp and paper production in the European Union, Waste Manage. 29 (2009) 293-308.

[79] S.Q. Yan, K. Sagoe-Crentsil, G. Shapiro, Properties of cement mortar incorporating de-inking waste-water from waste paper recycling, Constr. Build. Mater. 29 (2012) 51-55.

[80] M. Ugurlu, A. Gurses, C. Dogar, M. Yalcın, The removal of lignin and phenol from paper mill effluents by electrocoagulation, J. Environ. Manage. 87 (2008) 420-428.

[81] M.A.A. Razali, Z. Ahmad, M.S.B. Ahmad, A. Ariffin, Treatment of pulp and paper mill wastewater with various molecular weight of polyDADMAC induced flocculation, Chem. Eng. J. 166 (2011) 529-535.

[82] M. Manttari, M. Kuosa, J. Kallas, M. Nystrom, Membrane filtration and ozone treatment of biologically treated effluents from the pulp and paper industry, J. Membr. Sci. 309 (2008) 112-119.

[83] L. Fernandes, M.S. Lucas, M.I. Maldonado, I. Oller, A. Sampaio, Treatment of pulp mill wastewater by Cryptococcus podzolicus and solar photo-Fenton: A case study, Chem. Eng. J. 245 (2014) 158-165.

[84] T. Liu, H. Hu, Z. He, Y. Ni, Treatment of poplar alkaline peroxide mechanical pulping (APMP) effluent with Aspergillus niger, Bioresour. Technol. 102 (2011) 7361-7365.

[85] C.W. Bryant, Updating a model of pulp and paper wastewater treatment in a partial-mix aerated stabilization basin system, Water Sci. Technol. 62 (2010) 1248-1255.

[86] G. Matafonova, G. Shirapova, C. Zimmer, F. Giffhorn, V. Batoev, G. Kohring Degradation of 2, 4-dichlorophenol by Bacillus sp. isolated from an aeration pond in the Baikalsk pulp and paper mill (Russia), Int. Biodeterior. Biodegrad. 58 (2006) 209-212.

[87] M. Sandberg, O. Holbya, Black liquor and alkaline shocks in a multiple stage biological treatment plant, J. Environ. Eng. Sci. 7 (2008) 335-344.

[88] Z. Mahmood-khan, E.R. Hall, Biological removal of phyto-sterols in pulp mill ef fl uents, J. Environ. Manage. 131 (2013) 407-414.

[89] N.S. Deshmukh, K.L. Lapsiya, D.V. Savant, S.A. Chiplonkar, T.Y. Yeole, P.K. Dhakephalkar, D.R. Ranade, Upflow anaerobic filter for the degradation of adsorbable organic halides (AOX) from bleach composite wastewater of pulp and paper industry, Chemosphere 75 (2009) 1179-1185.

[90] T. Yilmaz, A. Yuceer, M. Basibuyuk, A comparison of the performance of mesophilic and thermophilic anaerobic filters treating papermill wastewater, Bioresour. Technol. 99 (2008) 156-163.

[91] K.-Y. Show, J.-H. Tay, Influence of support media on biomass growth and retention in anaerobic filters, Water Res. 33 (1999) 1471-1481.

[92] O. Yue, S. Han, M. Yue, B. Gao, O. Li, H. Yu, Y. Zhao, Y. Oi, The performance of biological anaerobic filters packed with sludge-fly ash ceramic particles (SFCP) and commercial ceramic particles (CCP) during the restart period: effect of the C/N ratios and filter media, Bioresour. Technol. 100 (2009) 50165620.

[93] W. Han, Q. Yue, S. Wu, Y. Zhao, B. Gao, Q. Li, Y. Wang, Application and advantages of novel clay ceramic particles (CCPs) in an up-flow anaerobic bio-filter (UAF) for wastewater treatment, Bioresour. Technol. 137 (2013) $171-178$.

[94] M. Narra, V. Balasubramanian, H. Mehta, G. Dixit, D. Madamwar, A.R. Shah Performance evaluation of anaerobic hybrid reactors with different packing media for treating wastewater of mild alkali treated rice straw in ethanol fermentation process, Bioresour. Technol. 152 (2014) 59-65.

[95] Y. Satyawali, D. Pant, A. Singh, R.K. Srivastava, Treatment of rayon grade pulp drain effluent by upflow anaerobic fixed packed bed reactor (UAFPBR), J. Environ. Biol. 30 (September) (2009) 667-672.

[96] Z. Bakhshi, G. Najafpour, N. Navayi, E. Kariminezhad, R. Pishgar, N. Moosavi, Recovery of UAPB from high organic load during startup for phenolic wastewater treatment, Chem. Ind. Chem. Eng. O. 17 (4) (2011) 517-524.

[97] T. Jong, D.L. Parry, Removal of sulfate and heavy metals by sulfate reducing bacteria in short-term bench scale upflow anaerobic packed bed reactor runs, Water Res. 37 (2003) 3379-3389.

[98] S. Bodkhe, Development of an improved anaerobic filter for municipal wastewater treatment, Bioresour. Technol. 99 (2008) 222-226.

[99] H. Gannoun, E. Khelifi, H. Bouallagui, Y. Touhami, M. Hamdi, Ecological clarification of cheese whey prior to anaerobic digestion in upflow anaerobic filter, Bioresour. Technol. 99 (2008) 6105-6111.

[100] A.P. Buzzini, E.C. Pires, Cellulose pulp mill effluent treatment in an upflow anaerobic sludge blanket reactor, Process Biochem. 38 (2002) 707-713.

[101] A.P. Buzzini, E.P. Gianotti, E.C. Pires, UASB performance for bleached and unbleached kraft pulp synthetic wastewater treatment, Chemosphere 59 (2005) 55-61. 
[102] S.Ã. Chinnaraj, G.V. Rao, Implementation of an UASB anaerobic digester at bagasse-based pulp and paper industry, Biomass Bioenergy 30 (2006) $273-277$.

[103] S. Zhenhua and L. Qiaoyuan, Treatment of wheat straw explosion pulping effluent with combined UASB-SBR process, in: 2nd International Papermaking and Environment, 2008, 1145-1149.

[104] A.G. Rao, A.N. Bapat, Anaerobic treatment of pre-hydrolysate liquor (PHL) from a rayon grade pulp mill: pilot and full-scale experience with UASB reactors, Bioresour. Technol. 97 (2006) 2311-2320.

[105] D. Puyol, A.F. Mohedano, J.L. Sanz, J.J. Rodríguez, Comparison of UASB and EGSB performance on the anaerobic biodegradation of 2,4-dichlorophenol, Chemosphere 76 (2009) 1192-1198.

[106] D. Jeison, J. Vanlier, Cake formation and consolidation: Main factors governing the applicable flux in anaerobic submerged membrane bioreactors (AnSMBR) treating acidified wastewaters, Sep. Purif. Technol. 56 (2007) 71-78.

[107] W.J. Gao, K.T. Leung, W.S. Qin, B.Q. Liao, Effects of temperature and temperature shock on the performance and microbial community structure of a submerged anaerobic membrane bioreactor, Bioresour. Technol. 102 (2011) 8733-8740.

[108] E.R. Hall, K.A. Onysko, W.J. Parker, "Enhancement of bleached kraft organochlorine removal by coupling membrane filtration and anaerobic treatment", Environ. Technol. 16 (1995) 115-126.

[109] K. Xie, H.J. Lin, B. Mahendran, D.M. Bagley, K.T. Leung, S.N. Liss, B.Q. Liao, Performance and fouling characteristics of a submerged anaerobic membrane bioreactor for kraft evaporator condensate treatment, Environ. Technol. 31 (2010) 511-521.

[110] H.J. Lin, K. Xie, B. Mahendran, D.M. Bagley, K.T. Leung, S.N. Liss, B.Q. Liao, Sludge properties and their effects on membrane fouling in submerged anaerobic membrane bioreactors (SAnMBRs), Water Res. 43 (2009) 3827 3837.

[111] W.J.J.J. Gao, H.J.J. Lin, K.T.T. Leung, B.Q.Q. Liao, Influence of elevated pH shocks on the performance of a submerged anaerobic membrane bioreactor, Process Biochem. 45 (2010) 1279-1287.

[112] M. Masuelli, J. Marchese, N.A. Ochoa, SPC/PVDF membranes for emulsified oily wastewater treatment, J. Membr. Sci. 326 (2009) 688-693.

[113] M.S. Kim, D.Y. Lee, D.H. Kim, Continuous hydrogen production from tofu processing waste using anaerobic mixed microflora under thermophilic conditions, Int. J. Hydrogen Energy 36 (2011) 8712-8718.

[114] K. Stamatelatou, A. Kopsahelis, P.S. Blika, C.A. Paraskeva, G. Lyberatos, Anaerobic digestion of olive mill wastewater in a periodic anaerobic baffled reactor (PABR) followed by further effluent purification via membrane separation technologies, J. Chem. Technol. Biotechnol. 84 (2009) 909-917.

[115] A. Charfi, N. Ben Amar, J. Harmand, "Analysis of fouling mechanisms in anaerobic membrane bioreactors”, Water Res. 46 (2012) 2637-2650.

[116] R. Grover, S. Marwaha, J. Kennedy, Studies on the use of an anaerobic baffled reactor for the continuous anaerobic digestion of pulp and paper mill black liquors, Process Biochem. 34 (1999) 653-657.

[117] F.I. Turkdogan, J. Park, E.A. Evans, T.G. Ellis, Evaluation of pretreatment using UASB and SGBR reactors for pulp and paper plants wastewater treatment, Water Air Soil Pollut. 224 (2013) 1512-1516.

[118] J. Sun, B. Zhang, R. Sun, Y. Li, J. Wu, Treatment of cornstalk fibrous pulp wastewater using Anaerobic Baffled Reactor (ABR): Effect of shock loading rates, Int. J. Environ. Pollut. 38 (1-2) (2009) 81-87.

[119] H. Rizvi, N. Ahmad, F. Abbas, I.H. Bukhari, A. Yasar, S. Ali, T. Yasmeen, M. Riaz, Start-up of UASB reactors treating municipal wastewater and effect of temperature/sludge age and hydraulic retention time (HRT) on its performance, Arabian J. Chem. 6 (2015).

[120] W.H. Parker, E.R. Hall, G.J. Farquhar, Assessment of design and operating parameters for high rate anaerobic dechlorination of segregated kraft mill bleach plant effluents, Water Environ. Res. 65 (1993) 264-270.

[121] J.-H. Ahn, C. Forster, A comparison of mesophilic and thermophilic anaerobic upflow filters treating paper-pulp-liquors, Process Biochem. 38 (2002) 256 261.

[122] D.T. Sponza, A. Uluköy, Kinetic of carbonaceous substrate in an upflow anaerobic sludge sludge blanket (UASB) reactor treating 2,4 dichlorophenol (2,4 DCP), J. Environ. Manage. 86 (2008) 121-131.

[123] D.T. Sponza, C. Cigal, Relationships between anaerobic consortia and removal efficiencies in an UASB reactor degrading 2,4 dichlorophenol (DCP), J. Environ. Manage. 87 (2008) 177-192.

[124] A. Buzzini, I.K. Sakamoto, M.B. Varesche, E.C. Pires, Evaluation of the microbial diversity in an UASB reactor treating wastewater from an unbleached pulp plant, Process Biochem. 41 (2006) 168-176.

[125] S.R. Hassan, N.Q. Zaman, I. Dahlan, Effect of organic loading rate on anaerobic digestion: Case study on recycled paper mill effluent using Modified Anaerobic Hybrid Baffled (MAHB) reactor, KSCE J. Civ. Eng. 19 (2015) $1271-1276$.

[126] J. Fernández-Rodríguez, M. Pérez, L.I. Romero, Comparison of mesophilic and thermophilic dry anaerobic digestion of OFMSW: Kinetic analysis, Chem. Eng. J. 232 (2013) 59-64.

[127] D. Bolzonella, C. Cavinato, F. Fatone, P. Pavan, F. Cecchi, High rate mesophilic, thermophilic, and temperature phased anaerobic digestion of waste activated sludge: a pilot scale study, Waste Manage. 32 (2012) 1196-1201.
[128] A.B. dos Santos, I.A.E. Bisschops, F.J. Cervantes, J.B. van Lier, The transformation and toxicity of anthraquinone dyes during thermophilic (55 degrees C) and mesophilic (30 degrees C) anaerobic treatments, J. Biotechnol. 115 (2005) 345-353.

[129] I.M. Alatiqi, A.A. Dadkhah, A.M. Akbar, M.F. Hamouda, Comparison between dynamics and control performance of mesophilic and thermophilic anaerobic sludge digesters, Chem. Eng. J. Biochem. Eng. J. 55 (1994) B55-B66.

[130] S. Bayr, M. Rantanen, P. Kaparaju, J. Rintala, Mesophilic and thermophilic anaerobic co-digestion of rendering plant and slaughterhouse wastes, Bioresour. Technol. 104 (2012) 28-36.

[131] J.-H. Ahn, C. Forster, The effect of temperature variations on the performance of mesophilic and thermophilic anaerobic filters treating a simulated papermill wastewater, Process Biochem. 37 (2002) 589-594.

[132] K. Bialek, A. Kumar, T. Mahony, P.N.L. Lens, V. O'Flaherty, Microbial community structure and dynamics in anaerobic fluidized-bed and granular sludge-bed reactors: influence of operational temperature and reactor configuration, Microb. Biotechnol. 5 (2012) 738-752.

[133] R.M. McKeown, D. Hughes, G. Collins, T. Mahony, V. O’Flaherty, Lowtemperature anaerobic digestion for wastewater treatment, Curr. Opin. Biotechnol. 23 (2012) 444-451.

[134] L. Zhang, T.L.G. Hendrickx, C. Kampman, H. Temmink, G. Zeeman, Codigestion to support low temperature anaerobic pretreatment of municipal sewage in a UASB-digester, Bioresour. Technol. 148 (2013) 560-566.

[135] F.E. Mosey, X.A. Fernandes, Patterns of hydrogen in biogas from the anaerobic digestion of milk-sugars, Water Sci. Technol. 21 (4-5) (1989) 187-196.

[136] M.H. Hwang, N.J. Jang, S.H. Hyun, I.S. Kim, Anaerobic bio-hydrogen production from ethanol fermentation: the role of $\mathrm{pH}, \mathrm{J}$. Biotechnol. 111 (2004) 297-309.

[137] R. Montañés, M. Pérez, R. Solera, Anaerobic mesophilic co-digestion of sewage sludge and sugar beet pulp lixiviation in batch reactors: Effect of $\mathrm{pH}$ control, Chem. Eng. J. 255 (2014) 492-499.

[138] X. Shi, O. Lefebvre, K.K. Ng, H.Y. Ng, Sequential anaerobic-aerobic treatment of pharmaceutical wastewater with high salinity, Bioresour. Technol. 153 (2014) 79-86.

[139] A.J. Ward, P.J. Hobbs, P.J. Holliman, D.L. Jones, Optimisation of the anaerobic digestion of agricultural resources, Bioresour. Technol. 99 (2008) 7928-7940.

[140] B. James, D. Ollis, Biochemical engineering fundamentals, 2nd ed., McGrawHill, New York, 1986.

[141] M. Sandberg, B.K. Ahring, Anaerobic treatment of fish meal process wastewater in a UASB reactor at high pH, Appl. Microbiol. Biotechnol. 36 (6) (1992) 800-804.

[142] A. Van Tran, Removal of COD and color loads in bleached kraft pulp effluents by bottom ashes from boilers, Environ. Technol. 29 (2008) 775-784.

[143] E.-M. Ekstrand, M. Larsson, X.-B. Truong, L. Cardell, Y. Borgström, A. Björn, J. Ejlertsson, B.H. Svensson, F. Nilsson, A. Karlsson, Methane potentials of the Swedish pulp and paper industry - A screening of wastewater effluents, Appl. Energy 112 (2013) 507-517.

[144] M.H. Gerardi, The Microbiology of Anaerobic Digesters, 1st ed., John Wiley \& Sons Inc, Hoboken, NJ, USA, 2003.

[145] D. Gapes, N. Frost, T. Clark, P. Dare, R. Hunter, A. Slade, Nitrogen fixation in the treatment of pulp and paper wastewaters, Water Sci. Technol. 40 (11-12) (1999) 85-92.

[146] H. Bouallagui, Mesophilic biogas production from fruit and vegetable waste in a tubular digester, Bioresour. Technol. 86 (2003) 85-89.

[147] Y. Lin, D. Wang, Q. Li, M. Xiao, Mesophilic batch anaerobic co-digestion of pulp and paper sludge and monosodium glutamate waste liquor for methane production in a bench-scale digester, Bioresour. Technol. 102 (2011) 3673-3678.

[148] C. Lin, P. Zhang, P. Pongprueksa, J. Liu, S.A. Evers, P. Hart, Pilot-scale sequential anaerobic-aerobic biological treatment of waste streams from a paper mill, Environ. Prog. Sustainable Energy 33 (2014) 359-368.

[149] W. Zhou, T. Imai, M. Ukita, F. Li, A. Yuasa, Effect of limited aeration on the anaerobic treatment of evaporator condensate from a sulfite pulp mill, Chemosphere 66 (2007) 924-929.

[150] Y.H. Kim, S.H. Yeom, J.Y. Ryu, B.K. Song, Development of a novel UASB/CO2stripper system for the removal of calcium ion in paper wastewater, Process Biochem. 39 (2004) 1393-1399.

[151] Z. Yue, W.-W. Li, H. Yu, Application of rumen microorganisms for anaerobic bioconversion of lignocellulosic biomass, Bioresour. Technol. 128 (2013) $738-744$.

[152] X. Yuan, Y. Cao, J. Li, B. Wen, W. Zhu, X. Wang, Z. Cui, Effect of pretreatment by a microbial consortium on methane production of waste paper and cardboard, Bioresour. Technol. 118 (2012) 281-288.

[153] Y. Baba, C. Tada, Y. Fukuda, Y. Nakai, Improvement of methane production from waste paper by pretreatment with rumen fluid, Bioresour. Technol. 128 (2013) 94-99.

[154] R. Shankar, L. Singh, P. Mondal, S. Chand, Removal of lignin from wastewater through electro- coagulation, World J. Environ. Eng. 1 (2013) 16-20.

[155] F.F. Renault, B. Sancey, J. Charles, N. Morin-Crini, P.-M. Badot, P. Winterton, G. Crini, Chitosan flocculation of cardboard-mill secondary biological wastewater, Chem. Eng. J. 155 (2009) 775-783.

[156] U. Tezel, E. Guven, T.H. Erguder, G.N. Demirer, Sequential (anaerobic/aerobic) biological treatment of Dalaman SEKA Pulp and Paper Industry effluent, Waste Manage. 21 (2001) 717-724.

[157] N.R. Bishnoi, R.K. Khumukcham, R. Kumar, Biodegradation of pulp and paper mill effluent using anaerobic followed by aerobic digestion, J. Environ. Biol. 27 (2006) 405-408. 
[158] P. Singh, I.S. Thakur, Colour removal of anaerobically treated pulp and paper mill effluent by microorganisms in two steps bioreactor, Bioresour. Technol. 97 (2006) 218-223.

[159] Y. Chuphal, V. Kumar, I.S. Thakur, Biodegradation and decolorization of pulp and paper mill effluent by anaerobic and aerobic microorganisms in a sequential bioreactor, World J. Microbiol. Biotechnol. 21 (2005) 1439-1445.

[160] D. Balabanič, A.K. Klemenčič, Presence of phthalates, bisphenol A, and nonylphenol in paper mill wastewaters in Slovenia and efficiency of aerobic and combined aerobic-anaerobic biological wastewater treatment plants for their removal, Fresenius Environ. Bull. 20 (2011) 86-92.

[161] M.S. Sheldon, P.J. Zeelie, W. Edwards, Treatment of paper mill effluent using an anaerobic/aerobic hybrid side-stream membrane bioreactor, Water Sci. Technol. 65 (2012) 1265-1272.

[162] S. Liang, Y. Kang, A. Tiraferri, E.P. Giannelis, X. Huang, M. Elimelech, Highly hydrophilic polyvinylidene fluoride (PVDF) ultrafiltration membranes via postfabrication grafting of surface-tailored silica nanoparticles, ACS Appl. Mater. Interfaces 5 (2013) 6694-6703.

[163] P. Le-Clech, V. Chen, T.A.G. Fane, Fouling in membrane bioreactors used in wastewater treatment, J. Membr. Sci. 284 (2006) 17-53.

[164] R. Lebrero, A.C. Gondim, R. Pérez, P.A. García-Encina, R. Muñoz, Comparative assessment of a biofilter, a biotrickling filter and a hollow fiber membrane bioreactor for odor treatment in wastewater treatment plants, Water Res. 49 (2014) 339-350.

[165] S.E. Jørgensen, Encyclopedia of Ecology, Elsevier, 2008.

[166] L.L. Barton, G.D. Fauque, Biochemistry, physiology and biotechnology of sulfate-reducing bacteria, Adv. Appl. Microbiol. 68 (2009) 41-98.

[167] B.R. Dhar, G. Nakhla, M.B. Ray, Techno-economic evaluation of ultrasound and thermal pretreatments for enhanced anaerobic digestion of municipal waste activated sludge, Waste Manage. 32 (2012) 542-549.

[168] A. Shui, W. Zhu, L. Xu, D. Qin, Y. Wang, Green sonochemical synthesis of cupric and cuprous oxides nanoparticles and their optical properties, Ceram. Int. 39 (2013) 8715-8722.

[169] L. Yunqin, W. Dehan, W. Shaoquan, W. Chunmin, Alkali pretreatment enhances biogas production in the anaerobic digestion of pulp and paper sludge, J. Hazard. Mater. 170 (2009) 366-373.

[170] S. Bayr, P. Kaparaju, J. Rintala, Screening pretreatment methods to enhance thermophilic anaerobic digestion of pulp and paper mill wastewater treatment secondary sludge, Chem. Eng. J. 223 (2013) 479-486.

[171] N. Wood, H. Tran, E. Master, Pretreatment of pulp mill secondary sludge for high-rate anaerobic conversion to biogas, Bioresour. Technol. 100 (23) (2009) 5729-5735.
[172] M. Saha, C. Eskicioglu, J. Marin, Microwave, ultrasonic and chemo-mechanical pretreatments for enhancing methane potential of pulp mill wastewater treatment sludge, Bioresour. Technol. 102 (17) (2011) 7815-7826.

[173] A.B. Cundy, L. Hopkinson, R.L.D. Whitby, Use of iron-based technologies in contaminated land and groundwater remediation: A review, Sci. Total Environ. 400 (2008) 42-51.

[174] A. Heidari, H. Younesi, Z. Mehraban, Removal of Ni(II), Cd(II), and Pb(II) from a ternary aqueous solution by amino functionalized mesoporous and nano mesoporous silica, Chem. Eng. J. 153 (2009) 70-79.

[175] L. Skipperud, B. Salbu, E. Hagebø, Speciation of trace elements in discharges from the pulp industry, Sci. Total Environ. 217 (1998) 251-256.

[176] A. Sanchez, S. Recillas, X. Font, E. Casals, E. Gonza, V. Puntes, Ecotoxicity of, and remediation with, engineered inorganic nanoparticles in the environment, Trends Anal. Chem. 30 (2011) 507-516.

[177] A.T.W.M. Hendriks, G. Zeeman, Pretreatments to enhance the digestibility of lignocellulosic biomass, Bioresour. Technol. 100 (2009) 10-18.

[178] J.Y. Zhu, X.J. Pan, Woody biomass pretreatment for cellulosic ethano production: Technology and energy consumption evaluation, Bioresour. Technol. 101 (2010) 4992-5002.

[179] A. Hagelqvist, Sludge from Pulp and Paper Mills for Biogas Production, Karlstad University Studies, Karlstad, 2013.

[180] A.Y. Zahrim, M.L. Gilbert, J. Janaun, Treatment of pulp and paper mill effluent using photo-fenton's process, J. Appl. Sci. 7 (2007) 2164-2167.

[181] S. Alatalo, E. Repo, E. Mäkilä, J. Salonen, E. Vakkilainen, M. Sillanpää, Adsorption behavior of hydrothermally treated municipal sludge \& pulp and paper industry sludge, Bioresour. Technol. 147 (2013) 71-76.

[182] M. Bassandeh, A. Antony, P. Le-Clech, D. Richardson, G. Leslie, Evaluation of ion exchange resins for the removal of dissolved organic matter from biologically treated paper mill effluent, Chemosphere 90 (2013) 1461-1469.

[183] H. Oeller, I. Demel, G. Weinberger, Reduction in residual COD in biologically treated paper mill effluents by means of combined ozone and ozone/uv reactor stages, Water Sci. Technol. 35 (1997) 269-276.

[184] J.J. Rueda-Márquez, M. Sillanpää, P. Pocostales, A. Acevedo, M.A. Manzano, Post-treatment of biologically treated wastewater containing organic contaminants using a sequence of $\mathrm{H}_{2} \mathrm{O}_{2}$ based advanced oxidation processes: photolysis and catalytic wet oxidation, Water Res. 71 (2015) 85-96.

[185] J. Jokela, J. Rintala, A. Oikari, O. Reinikainen, K. Mutka, T. Nyronen, Aerobic composting and anaerobic digestion of pulp and paper mill sludges, Water Sci. Technol. 36 (1997) 181-188. 